\title{
Chymotrypsin-like Elastase 1 is Required for Emphysema Progression
}

\author{
Mohit Ojha ${ }^{1}$, Rashika Joshi ${ }^{2}$, Emily Goodman ${ }^{3}$, Jana Lewis ${ }^{4,5}$, Qiang \\ Fan $^{2}$, Richard Schumann 6 , Aleksey Porollo ${ }^{7,8}$, Rachel Zemans, \\ Matthew Batie ${ }^{10}$, and Brian Varisco $2,7 *$
}

1-Lincoln Medical Center and Mental Health Center, New York, NY, USA

2-Critical Care Medicine, Cincinnati Children's Hospital Medical Center

3-Biology, Miami University Oxford, OH, USA

4-Biology, University of Arkansas at Pine Bluff, Pine Bluff, AR, USA

5-School of Medicine, Drexel University, Philadelphia, PA

6-Antibody and Immunoassay Consultants, Rockville, MD, USA

7-College of Medicine, University of Cincinnati, Cincinnati, OH, USA

8-Center for Autoimmune Genomics and Etiology, Cincinnati Children's Hospital Medical Center,

Cincinnati, OH, USA

9-University of Michigan, School of Medicine, Ann Arbor, MI, USA

10-Clinical Engineering, Cincinnati Children's Hospital Medical Center, Cincinnati, OH, USA

*To whom correspondence should be addressed; E-mail: brian.varisco@cchmc.org 
medRxiv preprint doi: https://doi.org/10.1101/2020.04.27.20075531; this version posted January 16, 2021. The copyright holder for this preprint

(which was not certified by peer review) is the author/funder, who has granted medRxiv a license to display the preprint in perpetuity.

All rights reserved. No reuse allowed without permission.

\section{ONE SENTENCE SUMMARY}

We find that Chymotrypsin-like Elastase 1 (CELAI) mediates progressive airspace destruction in mouse emphysema models, that human lung CELA1 expression and binding to lung matrix are associated with known emphysema risk factors, and that the KF4 anti-CELA1 monoclonal antibody inhibits elastolytic activity in human COPD lung. 


\section{ABSTRACT}

Progressive emphysema is an important element of chronic obstructive pulmonary disease (COPD). Except for $\alpha 1$-antitrypsin (AAT) replacement, disease modifying therapies do not exist. We show that Chymotrypsin-like Elastase 1 (CELA1) is required for emphysema progression using murine lung injury and aging models with correlative human data. CELAI is expressed in distal lung epithelial cells during lung development, is absent in mature human lung, and is re-expressed in mouse and human AT2 cells after injury. Human CELA1 mRNA levels increase with age, and smoking reduces AAT neutralization of CELA1. CELA1 binding to healthy human lung tissue is increased with biaxial strain. Anti-CELA1 KF4 monoclonal antibody detects residues 53-78 of hCELA1 and inhibits 30\% of lung elastolytic activity in COPD lung. We propose a CELA1-based risk model in which (1) CELA1 expression increases with age, (2) AAT neutralization of CELA1 is reduced by smoking, and (3) CELA1 binding to lung elastin increases with tissue distortion leading to airspace destruction and loss of lung function. CELA1 may represent a therapeutic target to prevent distal airspace destruction in COPD.

\section{INTRODUCTION}

The normal adult human lung contains between 274-790 million alveoli (1). The number of alveoli are established by the second decade of life, decrease with advancing age, and early-life events such as premature birth and lung injury can reduce peak alveolar number. Beginning in the 3rd decade of life, lung function slowly declines, with a host of genetic and environmental factors influencing the rate of alveolar loss. Among genetic factors, altered protease-antiprotease balance (e.g. $\alpha-1$ antitrypsin (AAT) deficiency) and defects in the structure of elastin microfibrils (e.g. Marfan Syndrome, Fibrillin 1 deficiency) accelerate airspace simplification. Environmental factors such as air pollution and cigarette smoke are risk factors for 
emphysema acting via multiple mechanisms such as increased inflammation and oxidation of AAT (2). The product of risk and exposure determines the rate at which airspace simplification proceeds with a patient exhibiting respiratory insufficiency once a threshold is crossed. If we possessed a more complete understanding of the processes that led to progressive loss of lung function, perhaps therapies could be developed to preserve respiratory health.

We hypothesized that Chymotrypsin-like Elastase-1 (CELA1) is an important mediator of alveolar destruction. Although CELAl is traditionally classified as a pancreatic enzyme, it is expressed in the murine $(3,4)$ and human (5) lung, reduces postnatal lung elastance, and mediates AAT-deficient emphysema (5). Like other pancreatic elastases, CELA1 binding to lung elastin is enhanced by localized tissue strain (6, 7). Lung elastin is increased in Celal $^{--}$mice compared to wildtype (5). We used mouse models of emphysema to show that CELAl is required for ongoing airspace destruction and show that in humans, CELA1 is expressed by injured alveolar type 2 (AT2) cells. We show that CELAl expression is associated with known COPD risk factors, including age, smoking, and pre-existing lung injury. We developed a new anti-CELA1 antibody which inhibits CELA1 elastolytic activity as a potential novel therapy for COPD. 


\section{RESULTS}

\section{Prolonged Expression of Celal Weeks After Lung Injury}

We assessed Celal mRNA levels following lung injury after tracheal administration of porcine pancreatic elastase (PPE) which causes alveolar destruction and remodeling. Celal mRNA was increased 3.5 and 2.3-fold 42- and 84-days following PPE administration (Figure 1A). Proximity ligation in situ hybridization (PLISH) for Celal mRNA at 42 days post-PPE demonstrated Celal expression in the peripheral lung (Figure 1B, Figure S1) where it was co-expressed with Surfactant protein B mRNA consistent with expression in alveolar type 2 (AT2) cells (Figure 1C). Cela1 protein increased at 1- and 3days post-PPE as a $\sim 70 \mathrm{kDa}$ species which is a complex of Cela1+AAT (6). This was likely due to leakage

of serum proteins into the airspace. Native, $28 \mathrm{kDa}$, Cela1 protein was increased approximately 3-fold at days 21 and 42 (Figure 1D\&E). In this PPE-mediated lung injury model, increased AT2 cell Celal expression persists for at least 6-weeks after the injury. 

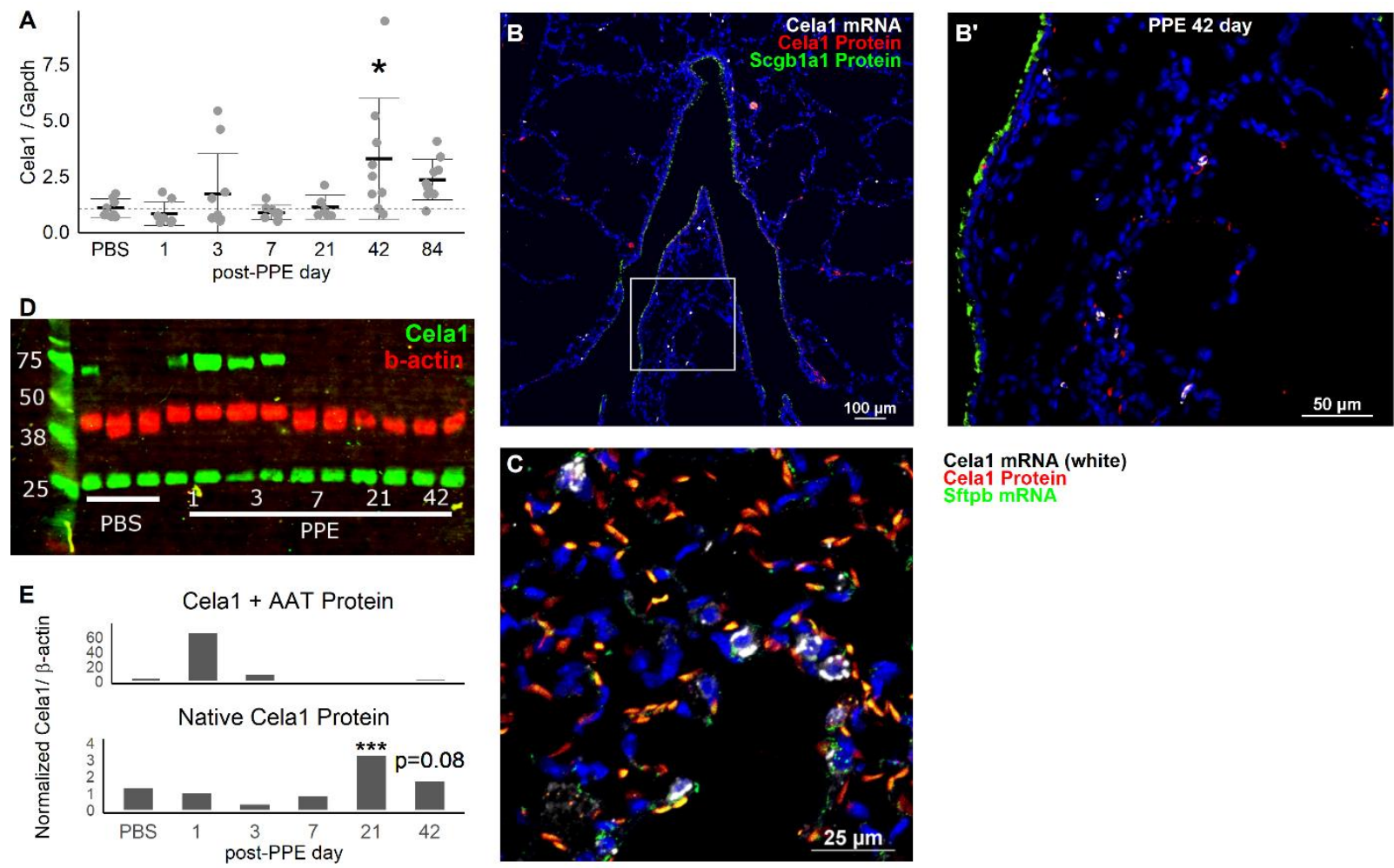

Cela1 mRNA (white)

Sela1 Protein

Figure 1: Celal Expression in a Murine Model of Emphysema. (A) Lung Celal mRNA was increased at 42 days after tracheal porcine pancreatic elastase (PPE). ANOVA $p=0.01, * p<0.05$ vs. PBS by Holm-Sidak post hoc test. (B) Proximity ligation in situ hybridization (PLISH) for Cela1 mRNA demonstrated co-expression of protein and mRNA in distal lung cells. Scgb1a1 immunostaining marks club cells. (C) PLISH for Celal and Surfactant protein B (Sftpb) mRNA with Cela1 immunostaining identified Cela1 protein and mRNA in a subset of alveolar type 2 cells. (D) Western blot of lung homogenates showed an early increase in the high molecular weight Cela1-AAT complex and a later 3-fold increase in native Cela1. (E) Only this later increase was statistically significant. ANOVA p <0.001, *** $\mathrm{p}<0.05$ vs. PBS by Holm-Sidak post hoc test. 
medRxiv preprint doi: https://doi.org/10.1101/2020.04.27.20075531; this version posted January 16, 2021. The copyright holder for this preprint (which was not certified by peer review) is the author/funder, who has granted medRxiv a license to display the preprint in perpetuity. All rights reserved. No reuse allowed without permission.

\section{Cela1 Is Required for Progression of Emphysema}

To test the role of Celal in emphysema pathogenesis, we compared mean linear intercept values of WT and Celal $^{--}$mice at 21, 42, and 84 days post-PPE. While Celal $^{-\leftarrow}$ and WT mice had similar airspace morphology at 21 days, Celal-deficient mice were protected from progressive emphysema at 42 and 84 days (Figure 2). Consistent with mRNA and protein expression, Celal did alter lung injury prior to 21 days, but was required for emphysema progression beyond 21 days.

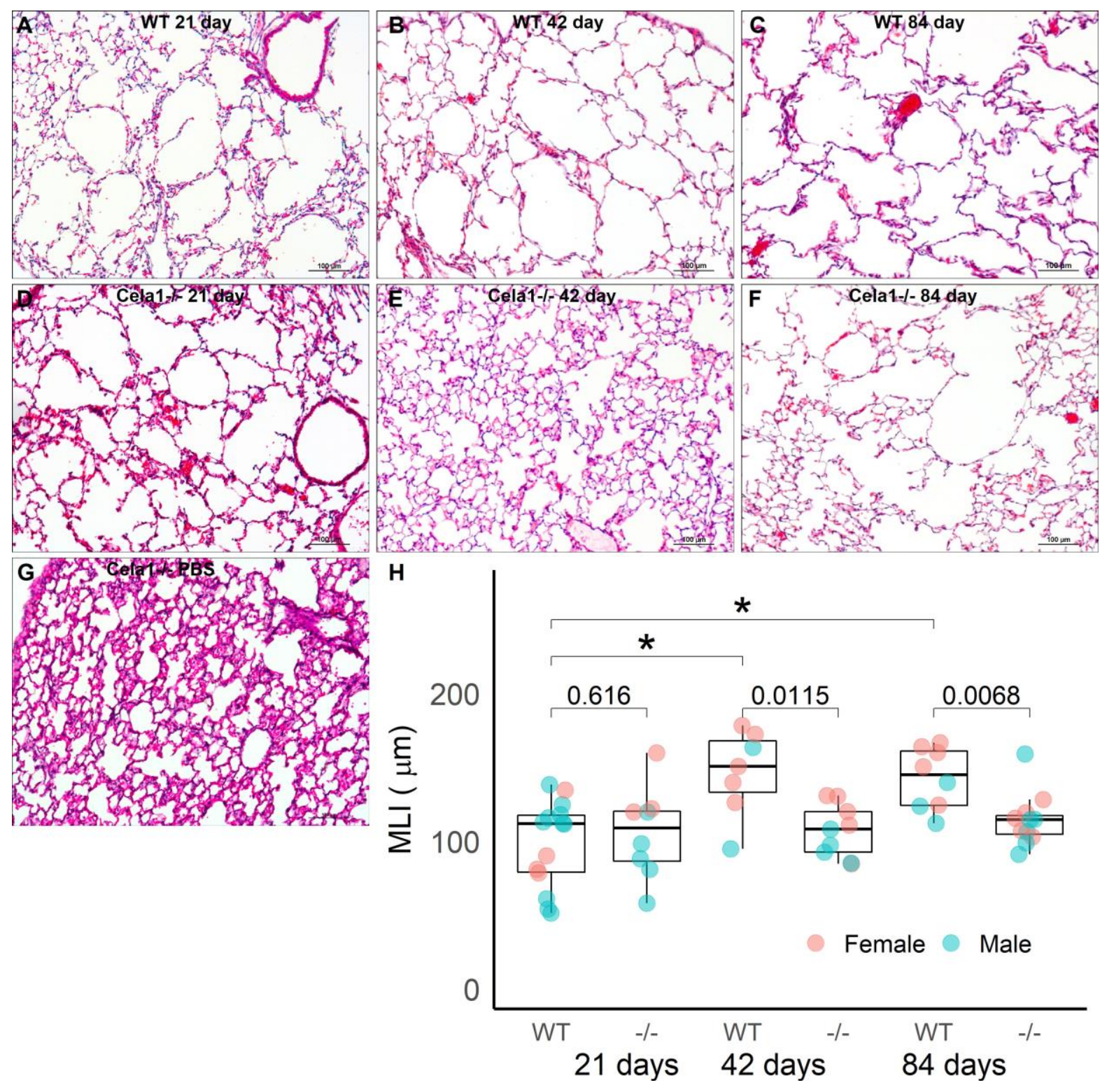


Figure 2: Celal Mediates Late Airspace Destruction in the PPE Emphysema Model. (A) Twenty-one days after tracheal PPE wild type (WT) lungs had significant emphysema. (B) This emphysema was worse at 42 days and (C) 84 days. (D) At 21 days, Cela1 ${ }^{-/}$mice had a level of emphysema similar WT. (E) However, at 42 days, the emphysema in Celal $^{-/}$mice did not progress. (F) The emphysema in Celal $^{--}$mice at 84 days was also unchanged. (G) PBS-treated Cela1 ${ }^{-/}$lung showed normal architecture. $(\mathrm{H})$ Mean linear intercept (MLI) quantification of emphysema in WT and Cela1 ${ }^{-\alpha}$ lungs post-PPE showed progression of emphysema at 42 and 84 days in WT but not Cela1 Celal $^{-/}$lungs treated with PPE. PBS-treated lung MLIs are omitted for clarity but were all $\sim 50 \mu \mathrm{m}$ and $\mathrm{p}<0.001$ by Kruskal-Wallis and Dunn's post hoc test for each PBS-PPE comparison. The comparisons of PPE-treated lung over time have Kruskal-Wallis $\mathrm{p}=0.001$ with Dunn's post hoc comparison $* \mathrm{p}<0.05$ shown. WT vs. Celal ${ }^{-\leftarrow}$ comparisons by Wilcoxon rank-sum test $\mathrm{p}$-values are shown directly. 


\section{Cela1 Mediates Age-related Airspace Simplification}

Alveolar loss and progressive airspace simplification occur with age in both mice and humans (8). Since Celal regulated late lung remodeling after PPE, we evaluated the lungs of 70-75-week-old mice without other intervention. Cela1 ${ }^{-1}$ mice were partially protected from the age-related airspace simplification seen in WT mice (Figure 3A-C). Although Cela1 protein levels did not change with age (Supplemental Figure 2), the lungs of aged knockout mice contained significantly more soluble (Figure 3D) and insoluble elastin (Figure S2) compared to age WT mice. Elastin architecture was preserved in aged Celal $^{\text {-1 }}$ mice (Figure 3E\&F). Since cellular senescence is known to be important in emphysema (9), we evaluated p16/p19, p21, and p53 proteins which were not significantly different between WT and Celal ${ }^{-1}$ (Supplemental Figure 2). 

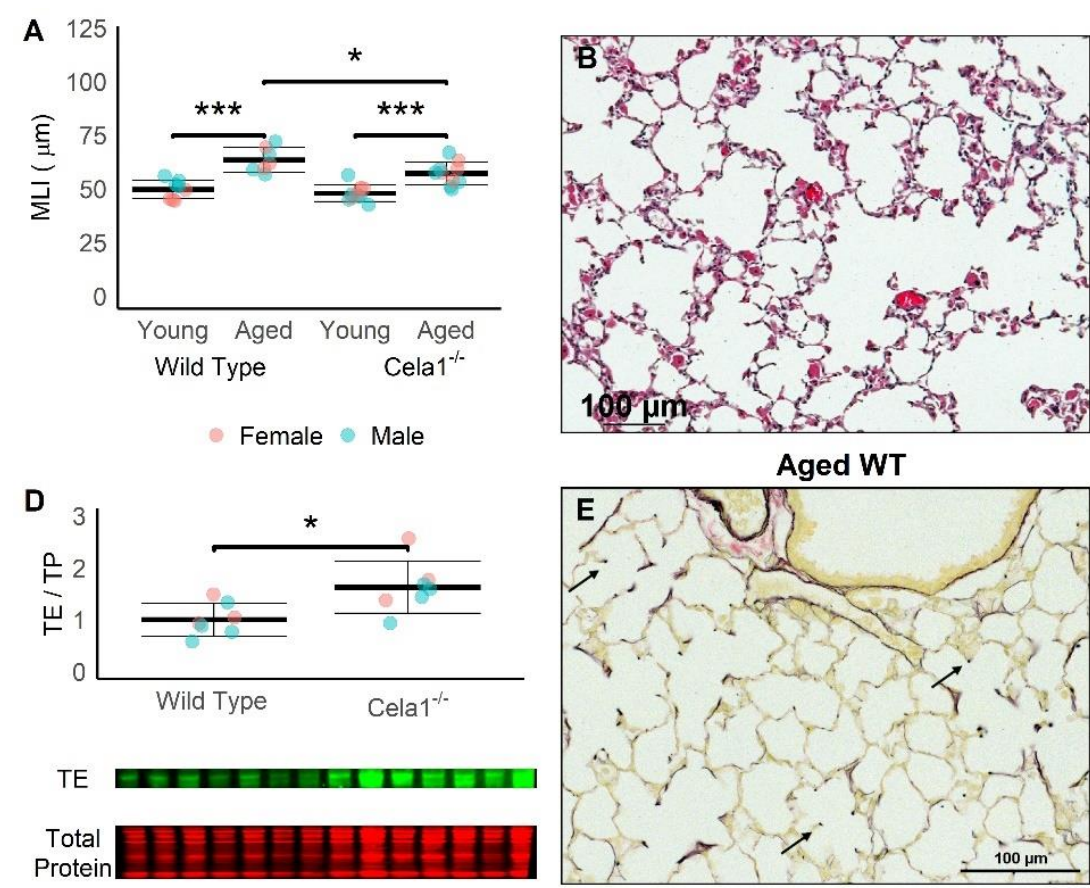

Aged WT

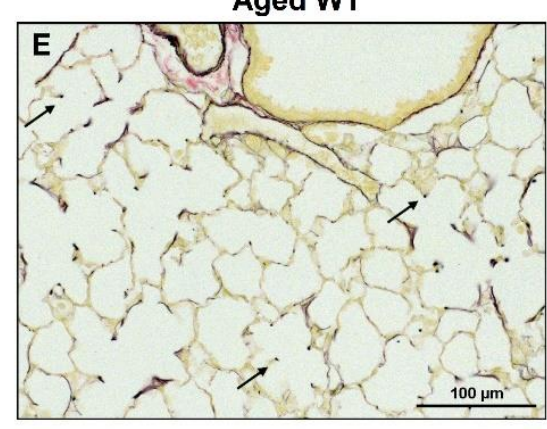

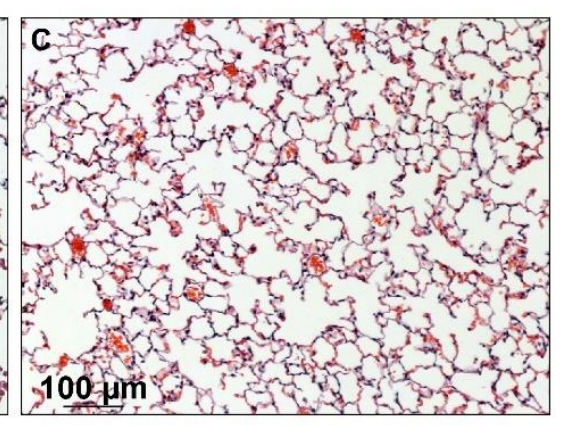

Aged Cela1-/-

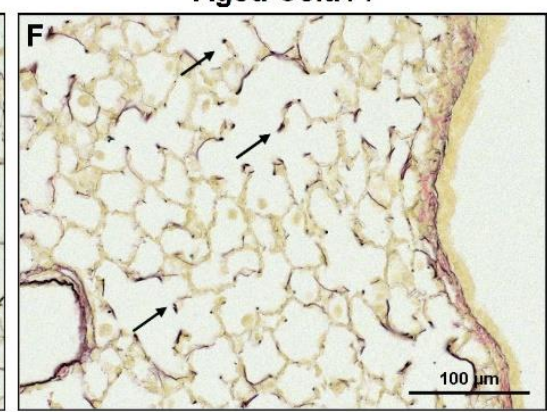

Figure 3: Celal in Age-Related Alveolar Simplification in Mice. (A) 70-75-week-old Cela1 ${ }^{-/}$mice (n=10) did not demonstrate the same degree of simplification as similarly aged WT mice $(n=7)$, ANOVA p<0.001, ${ }^{*} \mathrm{p}<0.05$, *** $\mathrm{p}<0.001$ by Holm-Sidak post hoc test. (B) Aged WT mice had loss of normal alveolar architecture that was preserved in (C) aged Celal $^{-\%}$ mice. (D) The lungs of 70-75-week-old knockout mice had more soluble tropoelastin (TE) than WT lungs. Central bars represent mean and whiskers standard deviation. *p<0.05 by Welch's t-test. (E) Aged WT mouse lung had less lung elastin with less-dense septal tip bundles than $(\mathrm{F})$ aged Cela1 $^{-/}$lung. 


\section{In mice, Cela1 is Expressed in Alveolar Type 2 Cells in Late Saccular Lung Development and Following Lung Injury}

Celal mRNA is increased during mouse lung development and plays a role in reducing postnatal lung elastance $(3,5)$. Flow cytometry showed that lung epithelial Celal protein was highest at gestational day 18.5 (E18.5) (10). Query of the LungGENS mouse lung single cell mRNA-seq database (11) showed that AT2 cell Celal expression was most notable at E18.5 and that at other time point Celal mRNA was present in a small subset of AT2 cells and myeloid cells (Figure 4A-C, Supplemental Figure 3). Expression of Celal in a subset of AT2 cells was confirmed in an independent single cell data set of adult mouse lung (Figure 4D) (12). In a dataset of sorted AT2 cells following tracheal lipopolysacharide administration (13), Celal mRNA was most abundant in injured AT2 cells (Figure 4E). Similarly, in a time course single-cell mRNA-seq dataset of lung cells following tracheal bleomycin administration, Celal mRNA was most abundant in activated AT2 cells (14) (Figure 4F). In a mouse lung organoid model of Interleukin-1 $\beta$ mediated alveolar type 1 (AT1) cell differentiation (15), Celal expression was higher in activated (Il-1 $\beta$ treated) AT2 cells, but not in control AT1 or damage-associated Type 2 progenitor (DAPT) cells—both of which express AT1 cell markers (Figure 5G). These data show that (1) AT2 cell Celal is increased during the late saccular stage of lung development, (2) it is expressed in rare AT2 cells and immune cells in healthy adult mouse lung, and (3) Celal expression cells increases after lung injury. 

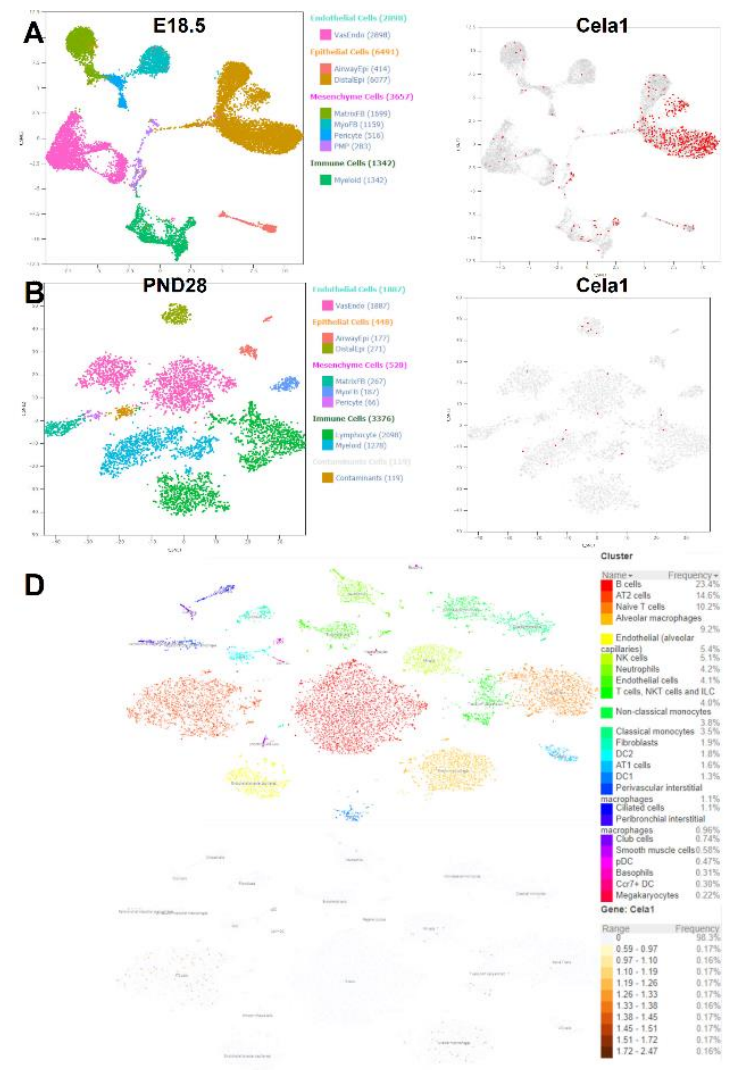

$\mathbf{F}$

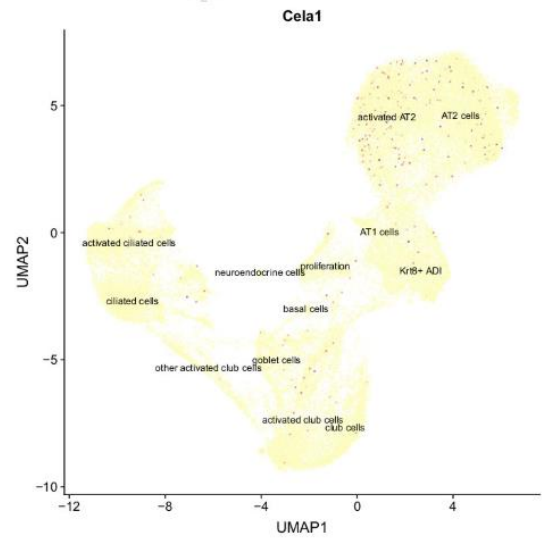

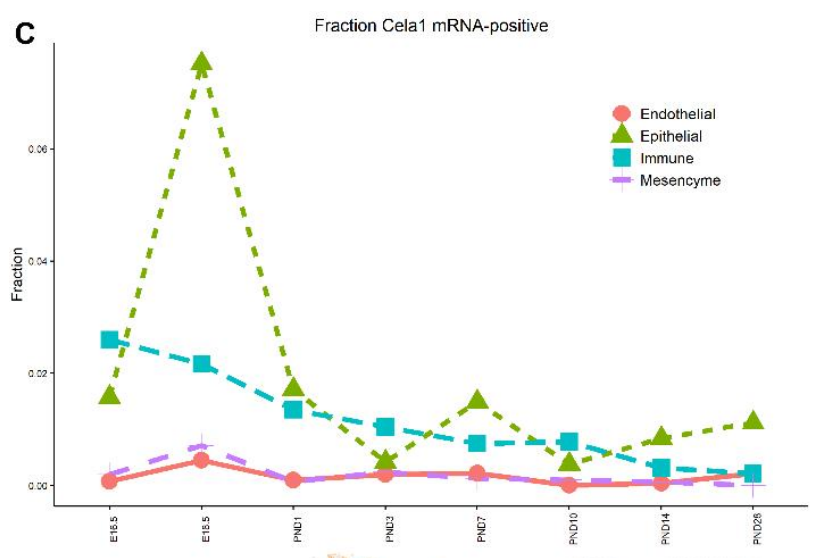

E
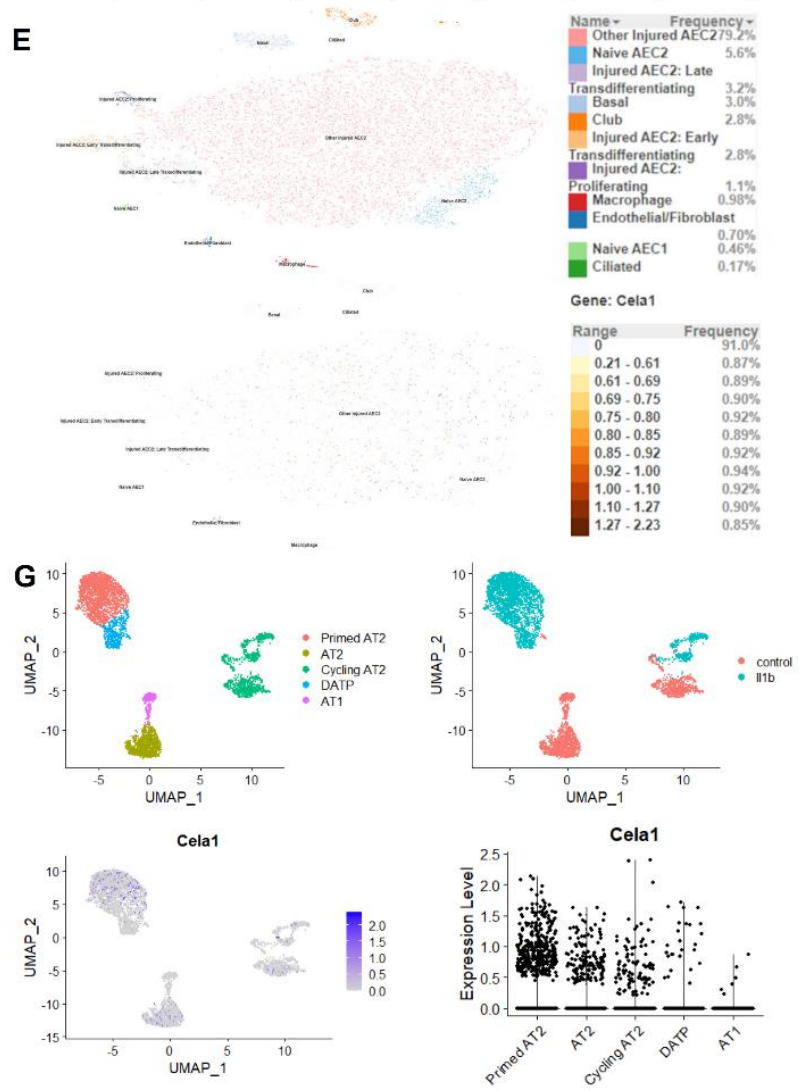

Figure 4: Cela1 Is Expressed in AT2 Cells in Late Saccular Development and After Lung Injury. (A) In C57BL/6 mice at E18.5, almost $8 \%$ of distal lung epithelial cells had detectable Celal mRNA. By comparison, $12.4 \%$ of these cells had detectable Surfactant protein B mRNA. (B) At 28 days of age, less than $2 \%$ of AT2 cells had detectable mRNA. (C) Except for the E18.5 timepoint, the percentage of cells with detectable Celal mRNA in immune and epithelial cell lineages was 1-2\%. Data are from LungGENS. (D) In the Reyfman, et al single cell mRNA-seq dataset from 12-week old C57BL/6 mice, there were rare 
medRxiv preprint doi: https://doi.org/10.1101/2020.04.27.20075531; this version posted January 16, 2021. The copyright holder for this preprint (which was not certified by peer review) is the author/funder, who has granted medRxiv a license to display the preprint in perpetuity.

All rights reserved. No reuse allowed without permission.

Celal-expressing AT2 cells and alveolar macrophages. (E) In data published by Riemondy, et al, lineagetraced AT2 cells from mice exposed to tracheal lipopolysaccharide showed a greater number of Celalexpressing cells in injured compared to uninjured AT2 cells. (F) In a single cell dataset of bleomycininduced injury published by Strunz, et al, Celal expression was more pronounced in activated AT2 cells than in other epithelial cells. (G) Mouse AT2 cell organoids treated with the inflammatory cytokine Interleukin-1 $\beta$ (IIlb) were noted to have enhanced alveolar type 1 (AT1) cell differentiation progressing through an activated AT2 cell state followed by a damage-associated Type 2 progenitor (DATP) state with expression at AT1 cell markers. Cela1 mRNA levels were most notable in activated AT2 cells (Choi, et al). 
medRxiv preprint doi: https://doi.org/10.1101/2020.04.27.20075531; this version posted January 16, 2021. The copyright holder for this preprint (which was not certified by peer review) is the author/funder, who has granted medRxiv a license to display the preprint in perpetuity.

All rights reserved. No reuse allowed without permission.

\section{CELA1 is Expressed in Clusters of Human Alveolar Type 2 Cells}

We performed immunostaining to assess for CELA1 protein in control and COPD human lung sections. CELA1-positive AT2 cells were identified as clusters in relatively preserved airspaces of COPD sections and were rarely found in control lung sections (Figure 5A-C). We used one $\mathrm{mm}^{2}$ regions of interest (ROI) in tile scanned immunostained sections to show that there were significantly more CELA1-positive cells that were clustered COPD specimens as compared to control (Figure 5D\&E). CELA1-expressing AT2 cell clusters were larger and more abundant in COPD lungs compared to controls, but CELA1-positive cells are rare in bullous emphysema.

We assessed CELA1 mRNA and protein in homogenate from control and COPD lung tissue. High and low molecular weight CELA1 forms were increased in COPD lung (Figure 5F), while CELA1mRNA levels of COPD specimens were greater than non-COPD smokers. CELA1 mRNA levels were increased in some non-smoker control specimens as well perhaps associated with other inflammatory processes (Figure 5G). These data show that AT2 CELA1 expression is increased in relatively normal appearing regions of COPD lung.

We queried several normal human lung single cell datasets to test for presence of CELA1 mRNA in AT2 cells. In a human fetal lung single-cell dataset of tracheal (15 and 21 week), small airway (15 and 18 week) and distal lung (15 and 18 week) cells, CELAl was detected only in rare tracheal T-cells (Supplemental Figure 4) (16). We analyzed data from the recently published human lung cell atlas which consists of $\sim 75,000$ cells from three adult patients who underwent lung lobe resection. Very rare CELAlexpressing AT2 cells, T-cells and monocytes/macrophages were identified (Supplemental Figure 5). Bulk mRNA-Seq of endothelial, epithelial, immune, and mesenchymal cells from 12 normal human donors identified CELAI expression in infant and child EpCam+ cells and in CD45+ cells of neonates, infants, and 
children (Supplemental Figure 5) $(17,18)$. This data is generally consistent with data in mouse showing expression of CELAI in the epithelial cells at a lung developmental stage consistent with viability (22-24 weeks); however, unlike mouse, human lung epithelial CELAI declines to virtually undetectable levels over the course of development with continued detection in rare immune cells. We then queried recently published single cell single cell datasets of patients with lung fibrosis and COPD. CELA1-expressing cells were present in AT2 cells (Figure 5H\&I, Supplemental Figure 6) (19-21). Rare immune cells also expressed CELA1 (Supplemental Figure 6). In human lung organoid models (22, 23), both native and induced pluripotent stem cell-derived AT2 cell organoids did not express CELA1 at baseline, but expression was increased at 2- and 4-days post-infection with SARS-CoV-2 virus (Supplemental Figure 5) (15). These data are consistent with very low level AT2 cell CELA1 expression at baseline with increased expression during injury. 
medRxiv preprint doi: https://doi.org/10.1101/2020.04.27.20075531; this version posted January 16, 2021. The copyright holder for this preprint (which was not certified by peer review) is the author/funder, who has granted medRxiv a license to display the preprint in perpetuity. All rights reserved. No reuse allowed without permission.

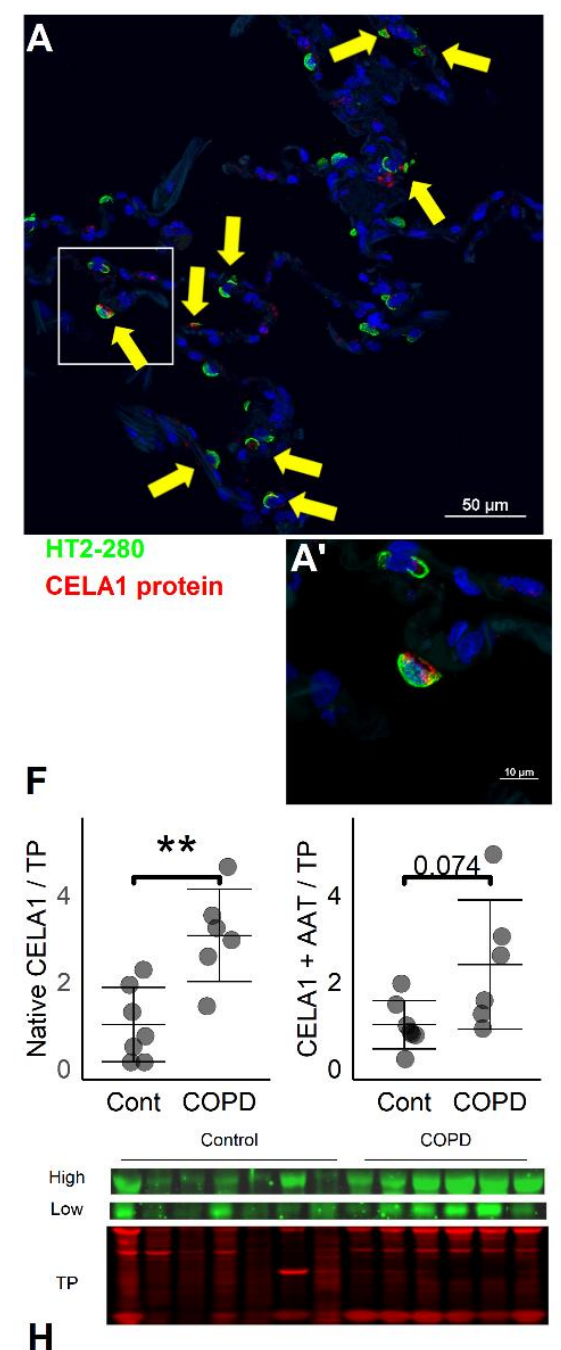

B

G

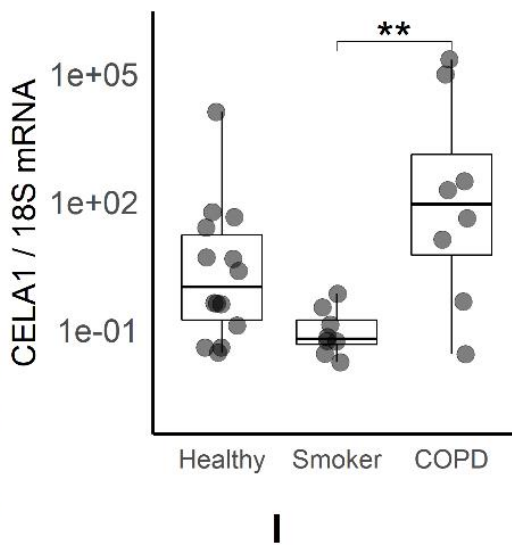

C

$5000 \mu \mathrm{m}$

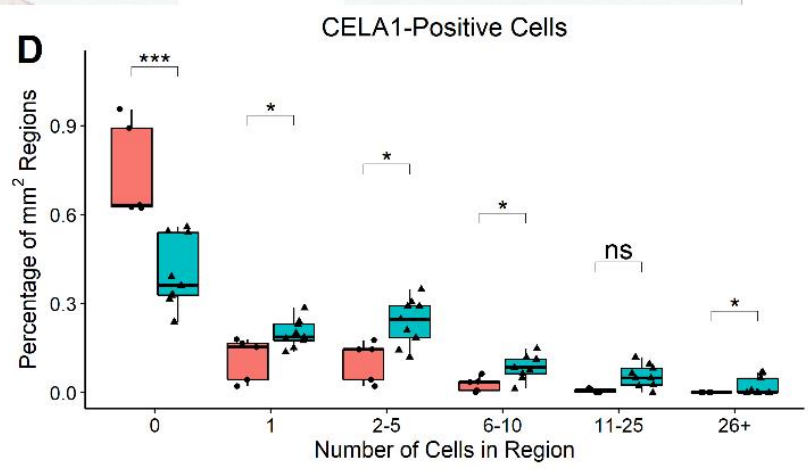

E Control $\mathrm{COPD}$

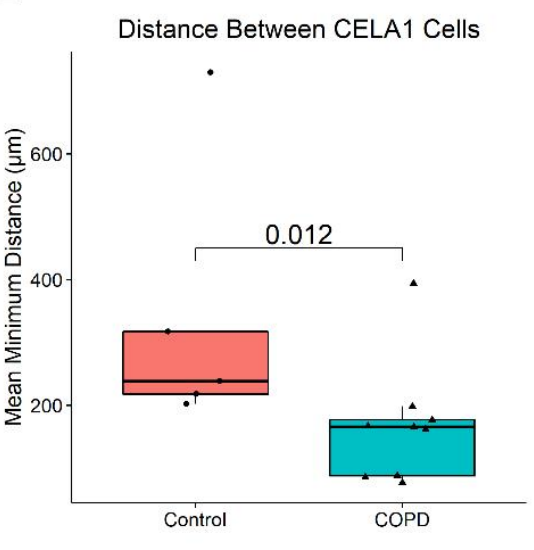

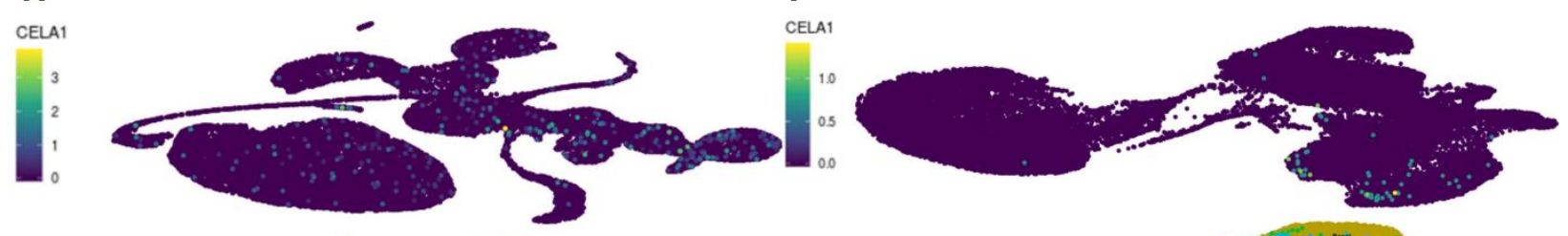
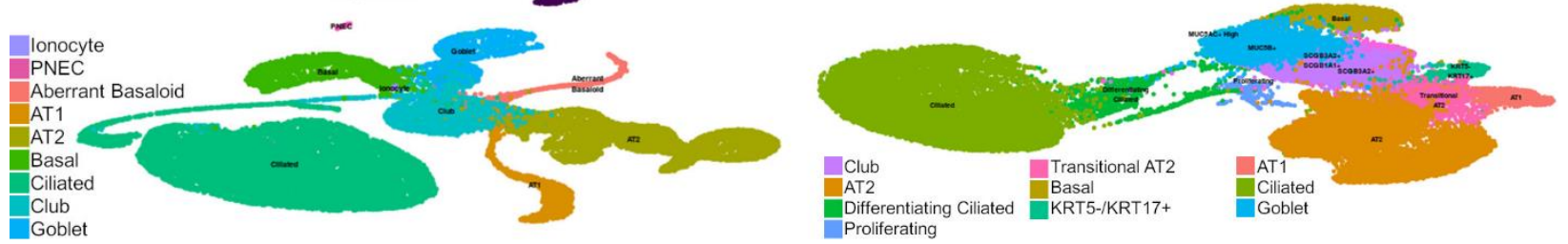
medRxiv preprint doi: https://doi.org/10.1101/2020.04.27.20075531; this version posted January 16, 2021. The copyright holder for this preprint (which was not certified by peer review) is the author/funder, who has granted medRxiv a license to display the preprint in perpetuity.

All rights reserved. No reuse allowed without permission.

Figure 5: CELA1 is Expressed in Clusters of AT2 Cells in COPD Lung. (A) CELA1 was co-stained by immunofluorescence with the AT2-cell apical surface antibody HT2-280 which identified regions of CELA1-positive AT2 cells in COPD lung specimens. (B) Immunohistochemistry for CELA1, tile scanning and thresholding (yellow) for CELA1-positive cells identified very few positive cells in control ( $\mathrm{n}=5$ ) lung specimens. (C) In COPD specimens ( $\mathrm{n}=9$ ), clusters of CELA1-positive cells were identified. (D) Clustering was quantified by overlaying a 1mm x $1 \mathrm{~mm}$ grid and counting the number of CELA1-objects per region, ${ }^{*} \mathrm{p}<0.05, * * * \mathrm{p}<0.001, \mathrm{~ns}=$ not significant by Wilcoxon test. (E) The average minimum distance between objects for each specimen was calculated and compared. Wilcoxon p-value shown. $(F)$ Western blot for CELA1 in 7 control and 6 COPD specimens (from a distinct set of specimens used in image analysis) showed greater amounts of native CELA1 and a trend towards greater amounts of AAT-neutralized CELA1 in COPD. ** $\mathrm{p}<0.01$ by Welch's t-test. (G) CELA1 mRNA levels were increased in COPD specimens compared to smoker lung specimens, Kruskal-Wallis $\mathrm{p}=0.002,{ }^{*} \mathrm{p}<0.05,{ }^{*} \mathrm{p}<0.01$ by Dunn's post hoc test. (H) Query of a single cell dataset of 32 pulmonary fibrosis, 28 control, and 18 COPD lung specimens identified CELA1-expression mostly in AT2 cells but also in other epithelial cell types. Only epithelial cells are shown. Data from Adams, et al and visualized in IPF Cell Atlas web tool. (I) Query of a single cell dataset of 20 fibrotic and 10 control lungs found CELA1 mRNA mostly in AT2 cells. Only epithelial cells are shown. Data from Habermann, et al and visualized in IPF Cell Atlas web tool. 
medRxiv preprint doi: https://doi.org/10.1101/2020.04.27.20075531; this version posted January 16, 2021. The copyright holder for this preprint (which was not certified by peer review) is the author/funder, who has granted medRxiv a license to display the preprint in perpetuity.

All rights reserved. No reuse allowed without permission.

\section{CELA1 anti-sera and Monoclonal Antibodies Reduce Human Lung Elastolytic Activity}

To ascertain the relative contribution of CELA1 to overall lung elastolytic activity, we performed a correlation analysis of protease and anti-protease mRNA levels with lung elastase, protease, and gelatinase activity. Among assayed genes, only CELA1 mRNA levels were significantly and positively correlated with lung elastase activity (Figure 6A). MMP8, MMP9, MMP12, Proteinase-3, and Cathepsin G levels were also higher in COPD compared to Smoker and non-Smoker lung (Supplemental Figure 6). These data support the concept that CELAl is an important contributor to the proteolytic environment in COPD.

Using median CELAl mRNA level as a cutoff, CELAl-low and -high specimens were incubated with pre-and post-immunization rabbit serum. Pre-immunization serum inhibited $14 \%$ and $20 \%$ of the lung elastolytic activity respectively, and post-immunization sera inhibited an additional 1\% and 5\% (Figure 6B). This was consistent with rabbit polyclonal anti-CELA1 antibodies neutralizing additional lung proteases beyond what was inhibited by serum anti-proteases.

We developed hybridomas from mice immunized against hCELA1 peptides (Figure 6C) and screened these hybridomas by ELISA for mCela1. Twenty positive clones were then screened against hCELA1 (Figure 6D), and the supernatants of the eight most strongly positive clones were tested for ability to inhibit hCELA1 elastolytic activity (Figure 6E). Hybridomas of the four clones with the greatest inhibitory capacity were expanded and antibodies purified from these hybridomas were tested by ELISAs of the immunizing peptides. The KF4 monoclonal antibody was IgG1 and identified Peptide-1 which matches residues 53-78 of hCELA1 (Figure 6F). The rabbit anti-sera detected all five peptides in addition to U-7318 which was used for immunization (Figure 6G). In a competitive inhibition experiment, KF4 signal was reduced after incubation with serially increasing concentrations of hCELA1 (Figure 6H). The 3D model of hCELA1 suggests that KF4 blocks substrate access to the 
medRxiv preprint doi: https://doi.org/10.1101/2020.04.27.20075531; this version posted January 16, 2021. The copyright holder for this preprint (which was not certified by peer review) is the author/funder, who has granted medRxiv a license to display the preprint in perpetuity.

All rights reserved. No reuse allowed without permission.

catalytic triad upon binding to its epitope (Figure 6I). Protein modeling of hCELA1 showed that KF4 is predicted to prevent substrate access to the catalytic triad (Figure 6I). Lastly, serial dilutions of KF4 were incubated with human lung homogenate and elastolytic activity quantified. KF4 reduced the elastolytic activity of COPD but not non-smoker or smoker lung (Figure 6J). KF4 is a functional inhibitor of hCELA1 and reduces the elastolytic activity of COPD lung. 
medRxiv preprint doi: https://doi.org/10.1101/2020.04.27.20075531; this version posted January 16, 2021. The copyright holder for this preprint (which was not certified by peer review) is the author/funder, who has granted medRxiv a license to display the preprint in perpetuity. All rights reserved. No reuse allowed without permission.

A

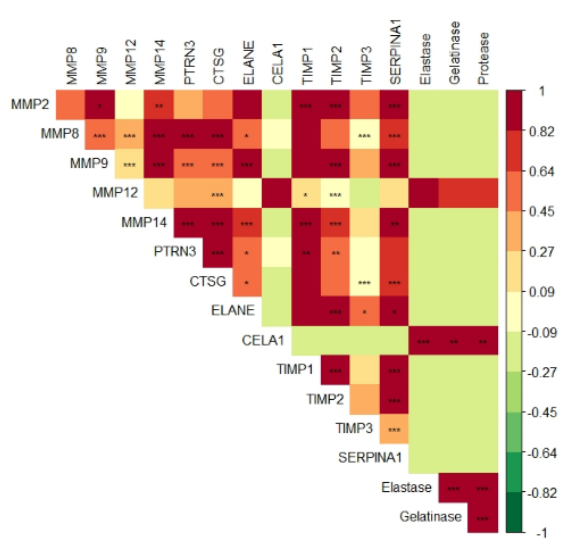

$\mathbf{F}$

Mouse Monoclonal ELISA

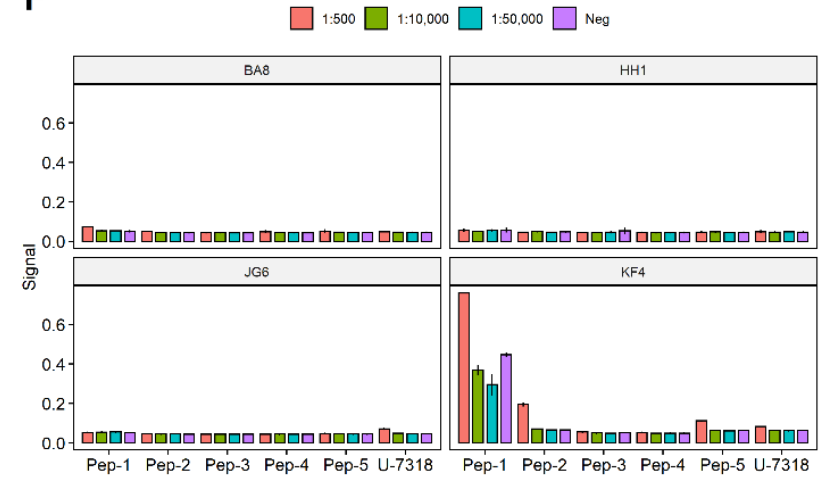

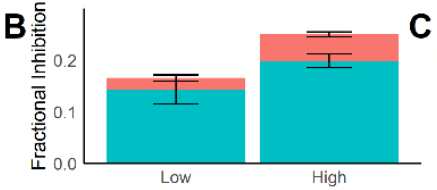

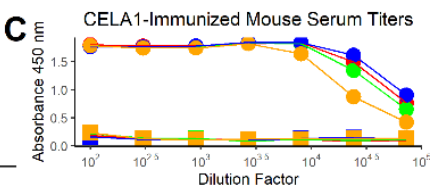

anti-CELA1 \erum

ELISA Screening

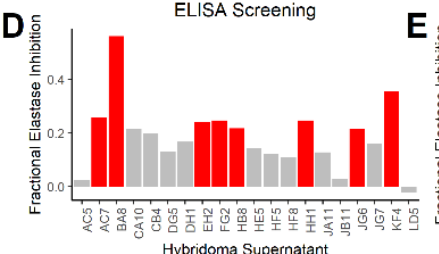

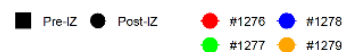

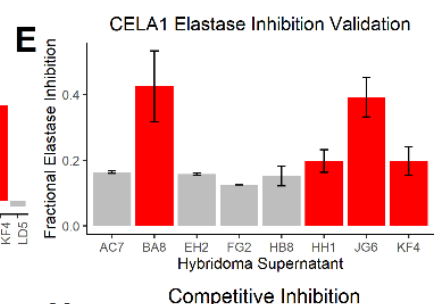

G

Rabbit Antisera ELISA
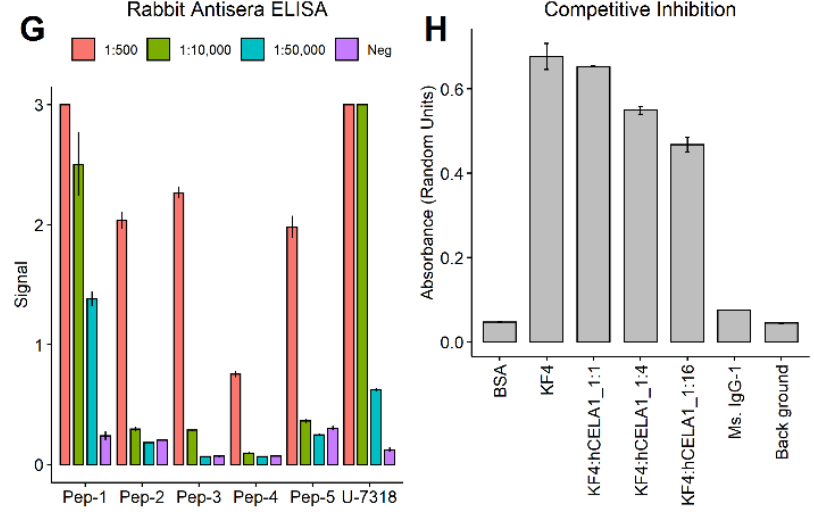

I

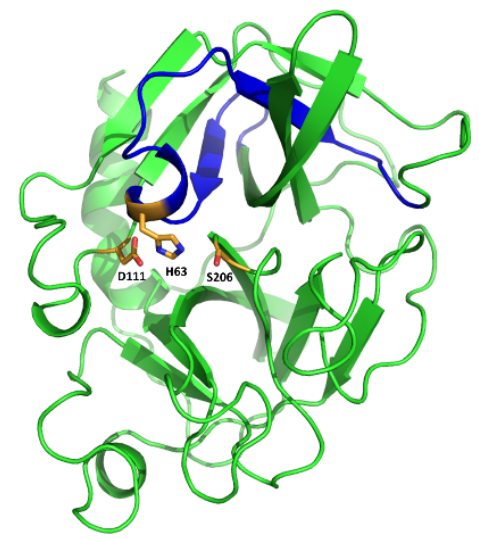

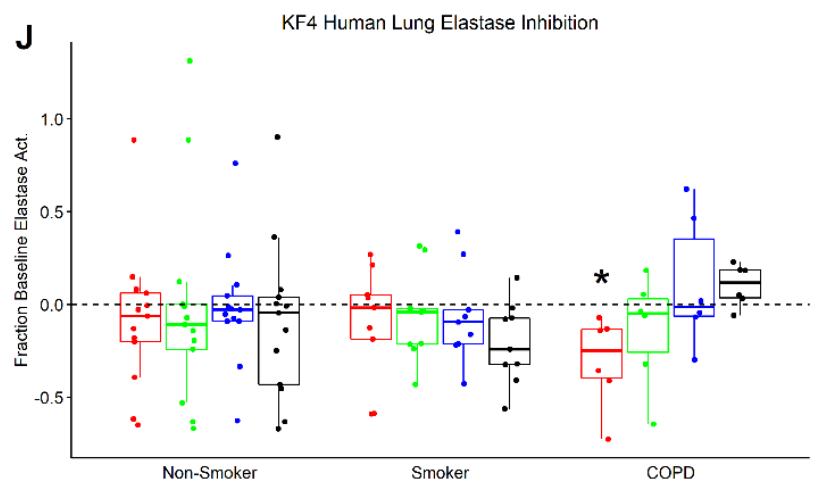

审 KF4695 fM 安 KF4 278fM 审 KF4 70 fM 审 IgG 695 fM 
medRxiv preprint doi: https://doi.org/10.1101/2020.04.27.20075531; this version posted January 16, 2021. The copyright holder for this preprint (which was not certified by peer review) is the author/funder, who has granted medRxiv a license to display the preprint in perpetuity.

All rights reserved. No reuse allowed without permission.

Figure 6: Anti-CELA1 Antibodies Inhibit Human Lung Elastolytic Activity. (A) A correlation of the mRNA levels of proteases and anti-proteases reported to be important in emphysema with lung elastolytic, gelatinase, and proteinase activity levels showed correlation of most proteases and anti-proteases, but CELA1 mRNA only correlated with MMP12 levels. Protease, gelatinase, and elastase activity levels were highly correlated with each other and with CELA1 mRNA levels. * $\mathrm{p}<0.05, *^{*} \mathrm{p}<0.01, *^{*} * \mathrm{p}<0.001$ by Pearson correlation after Benjamini-Hochberg correction. Specimens = 8 COPD, 9 Smoker, 8 Control. (B) The same lung homogenates were divided in half based on CELAl mRNA levels (low, and high). Quantification of change in lung elastase activity upon incubation with pre- and post-CELA1 peptide immunization rabbit serum showed that serum itself inhibited a substantial proportion of human lung elastase activity, but additional inhibition from anti-CELA antisera was only observed in the CELAl-high specimens. (C) CD1 mice immunized with five hCELA1 peptides showed strong antibody titers against hCELA1. (D) The supernatants of hybridomas created from the splenocytes of these mice were screened by ELISA to identify 8 candidates for functional screening. (E) Eight hybridoma supernatants were screened for ability to inhibit the elastolytic activity of hCELA1. (F) The four hybridomas with greatest anti-CELA1 activity were tested by ELISA against the peptides used to generate the antibodies and the peptide used for rabbit immunization (U-7318). The KF4 clone had a signal against Pep-1 and a weak signal against Pep-2. (G) As a positive control, the rabbit anti-sera was tested against all peptides and U-7318 showing reactivity against all wells. $(\mathrm{H})$ A competitive inhibition assay using KF4 and increasing concentrations of hCELA1 in plates coated with hCELA1 showed decreasing signal with increasing amounts of competitive inhibitor. (I) The predicted 3D structure of hCELA1 (Swiss-Model ID: Q9UNI1) with the Pep-1 segment highlighted in blue. The 3 amino acids of the catalytic triad (H63, D111, S206) are rendered with sidechains and labeled.

(J) The elastolytic activity of COPD but not non-smoker or smoker lung homogenates were reduced by KF4. Kruskal-Wallis $\mathrm{p}=0.013,{ }^{*} \mathrm{p}<0.05$ by Dunn's post hoc test. For all panels error bars represent standard 
medRxiv preprint doi: https://doi.org/10.1101/2020.04.27.20075531; this version posted January 16, 2021. The copyright holder for this preprint

(which was not certified by peer review) is the author/funder, who has granted medRxiv a license to display the preprint in perpetuity.

All rights reserved. No reuse allowed without permission.

deviation. 


\section{Genomics of human CELAI}

We wondered why CELAI had not been previously identified as a modifier gene in large COPD genomic studies (24-26). One hundred and fifteen CELAl variants were identified in Broad Institute (27), dbGap (28), and ClinVar (29) databases, but only five have allele frequencies of $>1 \%$, and none of these were predicted loss of function mutations by SIFT and PolyPhen-2 (30, 31). The most common predicted loss-offunction mutation (51735071, AG->A) had an allele frequency of $0.03 \%$ with one Caucasian and one Latino homozygote reported (Table 1). This conservation of CELA1 function is consistent with the invariant conservation of CELA1 in the placental mammal lineage (5). Thus, as CELA1 loss of-function mutations are rare, they would be unlikely to have been identified as protective in population-level genomics studies.

Table 1: Frequency of CELA1 Mutations

\begin{tabular}{|c|c|c|c|c|c|c|c|}
\hline Position & $\underline{\text { RSID }}$ & $\underline{\text { Reference }}$ & Alternate & $\begin{array}{c}\text { Protein } \\
\text { Consequence }\end{array}$ & Annotation & $\frac{\text { Functional }}{\text { Prediction }}$ & $\frac{\text { Allele }}{\text { Frequency }}$ \\
\hline 51737562 & rs17860300 & $\mathrm{T}$ & C & $\overline{\text { p.Met59Val }}$ & missense & $\overline{B e n i g n}$ & 0.2376 \\
\hline 51723598 & rs60311818 & A & AG & p.Leu210ProfsTer24 & frameshift & Benign & 0.2295 \\
\hline 51737607 & rs17860299 & G & A & p.Arg44Trp & missense & Benign & 0.1982 \\
\hline 51739648 & rs17860287 & C & G & p.Gln10His & missense & Benign & 0.09864 \\
\hline 51723499 & rs17860364 & $\mathrm{T}$ & C & p.Gln243Arg & missense & Benign & 0.09134 \\
\hline 51739640 & & G & A & p.Pro13Leu & missense & Benign & 0.00909 \\
\hline 51739625 & rs74336876 & C & $\mathrm{T}$ & p.Arg18His & missense & Benign & 0.007377 \\
\hline 51735144 & rs17860313 & C & $\mathrm{T}$ & p.Arg116His & missense & Benign & 0.001723 \\
\hline 51735071 & . & AG & A & p.Ala140ValfsTer47 & frameshift & Benign & 0.0005204 \\
\hline 51733775 & . & $\mathrm{C}$ & $\mathrm{T}$ & p.Ala160Thr & missense & Loss-of-Function & 0.0002924 \\
\hline
\end{tabular}


medRxiv preprint doi: https://doi.org/10.1101/2020.04.27.20075531; this version posted January 16, 2021. The copyright holder for this preprint

(which was not certified by peer review) is the author/funder, who has granted medRxiv a license to display the preprint in perpetuity.

All rights reserved. No reuse allowed without permission.

\section{Human Lung CELA1 Increases with Age}

CELA1 mRNA and protein levels were quantified in aged human lung specimens. Although levels were variable, CELAI mRNA levels increased with age and were not associated with sex or smoking status (Figure 7A). Despite mRNA findings, naive CELA1 protein levels were no different in young and aged lung (Figure 7B\&C), but AAT-bound CELA1 tended to be less in aged lung. Since this difference appeared to be driven by smoking, we compared 7 aged non-smoker lungs to 7 aged smoker lungs. Smoking reduced CELA1+AAT levels in these aged lung specimens. (Figure 7D, Supplemental Figure 7). This was consistent with reports of oxidized AAT having reduced anti-elastolytic activity (2). This data indicates that CELA1 expression increases with age and that AAT neutralization of CELA1 is reduced by smoking. These associative data suggest CELA1 may be important in human emphysema since both age and smoking are COPD risk factors. 

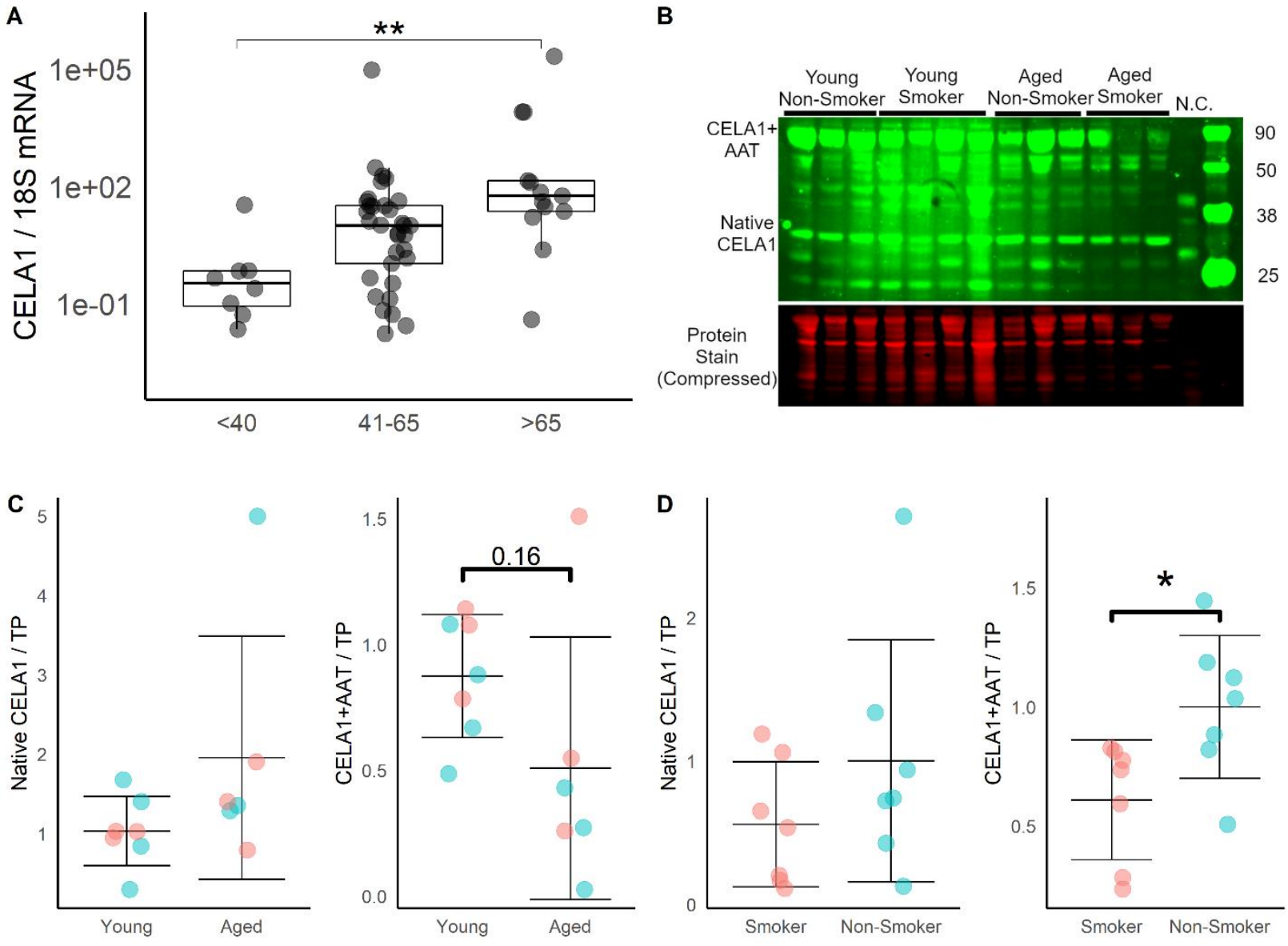

Figure 7: CELAl in Aged Human Lung. (A) Lung CELA1 mRNA levels increased with age in human lung specimens, Kruskal-Wallis $\mathrm{p}=0.002,{ }^{* *} \mathrm{p}<0.01$ by Dunn's post hoc test. (B) Western blot for CELA1 in young adult vs aged lung specimens. (C) Quantification of the low (native) and high (CELA1+AAT) molecular weight form of CELA1 shows little change in the amount of native CELA1 protein in aged lung and an overall reduction in the amount of CELA1+AAT in this aged lung. (D) Quantification of low and high molecular weight CELA1 in aged lung specimens. * $\mathrm{p}<0.05$ by Welch's t-test. 
medRxiv preprint doi: https://doi.org/10.1101/2020.04.27.20075531; this version posted January 16, 2021. The copyright holder for this preprint (which was not certified by peer review) is the author/funder, who has granted medRxiv a license to display the preprint in perpetuity.

All rights reserved. No reuse allowed without permission.

\section{Binding of CELA1 to Human Lung Tissue is Enhanced by Stretch}

We previously reported a stretch-inducible elastase activity in freshly sectioned mouse lungs (6) (20), that Celal protein bound to these areas of activity (10), and that Celal-deficient lung lacked stretchinducible lung elastase, activity (5). Archived lungs from non-lung organ donors and COPD explants were analyzed for stretch-inducible lung elastase activity and for binding of recombinant CELA1 and bovine serum albumin using a 3D-printed biaxial stretching device (Supplementary Figure 8). Elastase activity, albumin binding and CELA1 binding signals were normalized to tissue autofluorescence and measured as change in normalized signal divided by bidirectional strain or the time equivalent for unstretched sections (i.e. slope of a plot of signal vs strain for each section, Supplementary Figure 8). We identified no evidence of stretch-inducible lung elastase activity or increased biding of albumin to lung tissue with stretch, but there was a significant increase in the binding of CELA1 to lung tissue with stretch (Figure 8). CELA1 binding to human lung tissue is enhanced with stretch although this binding is less in COPD than healthy lung perhaps owing to fibrotic changes and/or altered stretch mechanics in end-stage COPD lung. This data in combination with our previous report that hydroxyproline cross links inhibit CELA1-mediated elastolysis (5) suggest that stretching enhances the accessibility of lung elastin fibers to CELA1. 

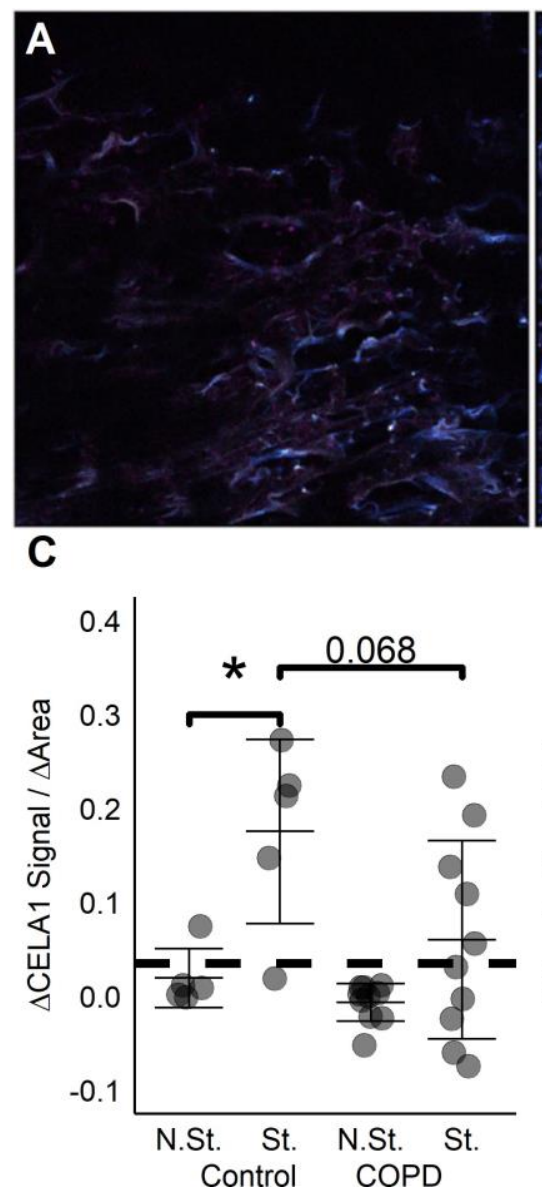

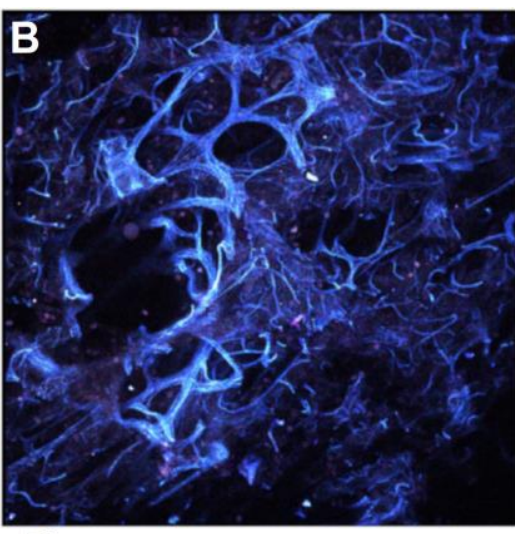

D

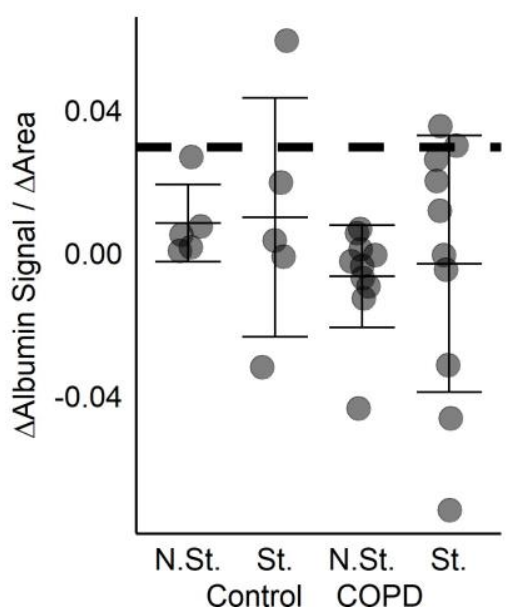

Tissue Autofluorescence

Elastase Activity

Albumin

CELA1 (white)

$\mathbf{E}$

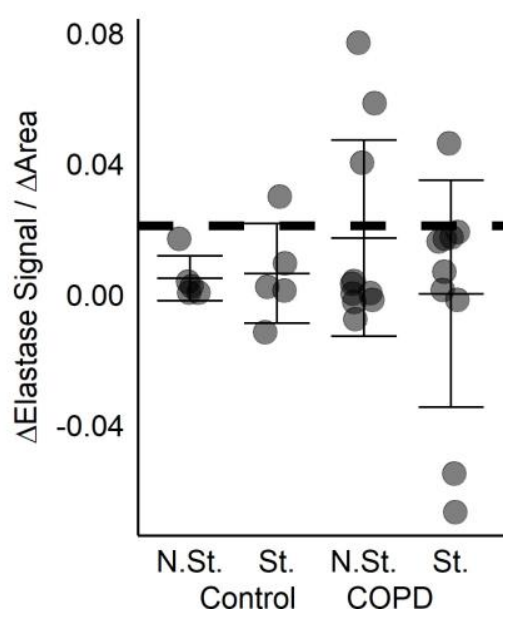

Figure 8: Stretch-Inducible Binding of CELA1 to Healthy Human Lung Tissue. (A) Sectioned, frozen human lung tissue was mounted on a biaxial stretching device and imaged in the presence of elastin in situ zymography substrate and fluorophore labeled CELA1 and albumin. Unstretched tissue showed little signal in any of the three channels and was imaged repetitively at the same time interval as stretched lung sections. (B) Stretched lung showed increased binding of CELA1 with stretch but little albumin binding or elastase activity. (C) Control lung ( $\mathrm{n}=5)$ had increased binding of CELA1 to lung tissue with stretch while lung tissue from COPD subjects $(\mathrm{n}=10)$ did not. ANOVA $\mathrm{p}=0.001$ (not shown), ${ }^{*} \mathrm{p}<0.05$ by Holm-Sidak post hoc test. (D) As a control, albumin binding to the lung tissue did not increase in response to stretch. (E) Stretch did not induce lung elastase activity. Dashed lines indicate the signal of lung incubated without substrate. 


\section{DISCUSSION}

This study is the first to report a role for CELAI in lung matrix remodeling in non-AAT-deficient emphysema. We found that CELA1 was expressed in clusters of AT2 cells in architecturally-preserved regions of COPD lung sections, that there was a high level of correlation of CELAI expression and lung elastolytic activity, and that a monoclonal anti-CELA1 antibody reduced human lung elastolytic activity. Based on our findings in mouse and human lung, we propose a 3-step mechanism by which CELAl mediates progressive airspace destruction. First, localized injury to AT2 cells increases CELA1 expression. For unclear reasons, this expression increases with age. Second, smoking reduces AAT neutralization of CELA1. It is likely that oxidation of AAT by cigarette smoke exposure accounts for this reduction (19). Third, disruption of normal lung architecture increases regional strain and enhances binding of CELA1 to lung elastin causing additional lung tissue destruction. This three-step mechanism is consistent with the known COPD risk factors of age, smoking, and preceding lung injury and explains why individuals with emphysema can experience disease progression despite smoking cessation.

AAT neutralizes a host of serine proteases (32). We previously reported that Celal deficient mice were protected from emphysema in an anti-sense oligonucleotide model of AAT deficiency (5). While multiple studies demonstrate that mutations in AAT strongly predispose to emphysema even in the absence of AAT deficiency $(33,34)$, no such correlative data exists for CELA1. Given the rarity of CELA1 loss of function alleles (the most common has an allele frequency $0.03 \%$ and thus homozygous loss of function frequency would be predicted to be 0.09 per $1,000,000$ ), it is not surprising the CELA1 should not have been identified in COPD genome-wide association studies (GWAS). It is unclear why CELA1 should be so highly conserved since $\mathrm{Cela1}^{- \text {- }}$ mice are viable, fertile, and born at expected Mendelian ratios (5). 
medRxiv preprint doi: https://doi.org/10.1101/2020.04.27.20075531; this version posted January 16, 2021. The copyright holder for this preprint (which was not certified by peer review) is the author/funder, who has granted medRxiv a license to display the preprint in perpetuity.

All rights reserved. No reuse allowed without permission.

We are unaware of any other protease or anti-protease with expression levels that change with age or are expressed in a regionalized manner. AAT levels are relatively stable throughout life (35), and to the best of our knowledge, age-related changes in other emphysema-associated proteases have not been studied. What regulates regionalized Celal expression requires further investigation.

The binding of CELA1 to lung matrix with strain is consistent with previous reports that pancreatic elastase binds lung elastin fibers as a vector of strain (7). Elastin degradomic data demonstrated that elastin crosslinking domains retarded CELA1-mediated elastolysis (5) suggesting that mechanical perturbation of elastin fibers permits CELA1 access to previously hidden sites. The levels of strain used in our study likely exceed that in human lung physiology, but the time course of the experiment was also necessarily shorter than the years over which emphysema progresses in humans. Such dynamic studies of ex vivo human lung are a novel approach to understanding human lung physiology.

Our CELA1 inhibition experiments suggest the potential to develop anti-CELA1 therapies to slow or halt progressive airspace destruction in established emphysema. The inhibition of $\sim 25 \%$ of COPD lung elastolytic activity comparable to the $30 \%$ reduced activity seen in Celal $^{-\%}$ mice during lung development (6). Interestingly, lung elastase, gelatinase, and overall protease activity were highly correlated with each other and were positively and significantly correlated with CELAI mRNA levels but not mRNA levels of other assayed proteases or anti-proteases. To the best of our knowledge, in animal models of emphysema, no other protease has been shown to have differential roles in the establishment and progression of emphysema. Neutrophil elastase $(36,37)$, cathepsins $(38)$, and matrix metalloproteinases (39-41) each have roles in the establishment of emphysema, but roles in emphysema progression have not been tested. Our data showing correlation of the mRNA levels of many of these proteases with each other but not with CELA1 and MMP12 suggest the operation of at least two different remodeling programs.

We point out several limitations of this study. First, the mouse PPE model of emphysema may not 
medRxiv preprint doi: https://doi.org/10.1101/2020.04.27.20075531; this version posted January 16, 2021. The copyright holder for this preprint (which was not certified by peer review) is the author/funder, who has granted medRxiv a license to display the preprint in perpetuity.

All rights reserved. No reuse allowed without permission.

accurately capture many of the processes that lead to airspace destruction in human disease. However, our findings that CELAI plays a role in late, but not early, remodeling processes may mean that the method of injury is less important that the presence of airspace destruction. Second, since we collected left lung lobes prior to lung inflation, isobaric inflation could have contributed to larger intercept and diameter values than may have been obtained if closed chest, isovolumetric inflation had been used. This approach also precluded measurement of whole lung volumes. Third, we did not evaluate immunological or vascular changes in PPE-treated mice. In repetitive, low-dose PPE exposures, both pulmonary hypertension and an increase in M1 macrophages have been noted, though the mechanisms and consequences of thesefindings are unclear (42). Our control human lung was largely from organ donors whose lungs were unsuitable for transplantation. Thus, our human control specimens likely had some element of acute lung injury. Fourth, we did not prove that the KF4 antibody prevented emphysema progression in murine models of emphysema. The first of several hurdles to be overcome before pursing this experiment is identifying a preparation or modification of the KF4 antibody that will penetrate into the lung extracellular space. While mouse lung injury and human lung organoid SARS-CoV-2 infection suggest that CELAl expression increases with a few days of injury, the increase in Celal after tracheal PPE was seen several weeks later. This could be due to the severity of injury induced by PPE or could indicate that the lung remodeling program of emphysema is not exactly the same as in these models and proceeds at a different pace.

\section{CONCLUSION}

CELA1 plays an important role in emphysema progression and its inhibition could provide protection from lung function decline in diseases of alveolar destruction such as COPD.

\section{METHODS}


See the Online Supplement for detailed methods.

\section{Animal Use}

Animal use was approved by the CCHMC Institutional Animal Use and Care Committee (2017-0064). Using the methods of Dunnill (43), mean linear intercepts in lungs of 8-12 week-old Celal ${ }^{-/}$and WT mice on the C57BL/6 background were administered 2 units of porcine pancreatic elastase (PPE) in $100 \mu L$ PBS (44) and untreated mice aged 70-75 weeks were determined. anti-CELA1 polyclonal antibody was generated using a single female New Zealand rabbit using the same peptide and methods as reported for guinea pig (3).

\section{Human Lung Tissue}

Human tissue utilized under a waiver from the CCHMC IRB (2016-9641). COPD and aged human lung specimens were obtained from the NHLBI Lung Tissue Consortium and control and COPD specimens from the National Jewish Health Human Lung Tissue Consortium.

\section{Enzymatic Assays}

Human lung protease, gelatinase, and elastase activity was quantified using Enzcheck fluorometric assays (ThermoFisher) and elastase activity defined as rate of signal change. For comparative inhibition assays (i.e. antibody inhibition) the fractional change vs. untreated was used for comparisons.

\section{Proximity Ligation in situ Hybridization (PLISH) and Immunofluorescence}


medRxiv preprint doi: https://doi.org/10.1101/2020.04.27.20075531; this version posted January 16, 2021. The copyright holder for this preprint (which was not certified by peer review) is the author/funder, who has granted medRxiv a license to display the preprint in perpetuity.

All rights reserved. No reuse allowed without permission.

Using oligos in Supplemental Table 1 and previously published methods (45), CELAI and Sftpb mRNAs were visualized with immunofluorescent co-staining using antibodies outlined in the supplement.

\section{PCR}

Taqman and Sybr Green PCR was used for mouse and human lung PCR using primers in Supplemental Tables $2 \& 3$.

\section{Ex vivo Human Lung Stretch}

Using a previously described lung stretching technique and device $(5,6,10)$, the stretch-dependent binding of recombinant CELA1, albumin, and elastolytic activity of frozen human lung sections was determined.

\section{ACKNOWLEDGEMENTS}

Reagents and Tissues: We would like to acknowledge Dr. William Janssen and the National Jewish Health

Human Lung Tissue Consortium in Denver, Colorado for providing control lung tissue specimens. This study utilized biological specimens and data provided by the Lung Tissue Research Consortium (LTRC) supported by the National Heart, Lung, and Blood Institute. Confocal imaging support was provided by the Cincinnati Children's Hospital Confocal Imaging Core.

\section{FUNDING}

A1 Foundation Research Award 498262 (Varisco), NHBLI R01141229 (Varisco), NHLBI K08HL131261 (Varisco).

\section{COMPETING INTERESTS}


Varisco/CCHMC (62/940,302 "Cela1 Inhibition to treat emphysema and lung disease in alpha1 antitrypsin deficiency"

Varisco/CCHMC (63/009,134 "Cela-1 Inhibition to Treat Lung Disease"

\section{DATA AND MATERIALS AVAILABILITY}

All data and code associated with this study are available in the main text or the supplementary materials.

The publicly available datasets used include : BioProject accession PRJNA632939, GeoDatasets GSE144468, and Array Express E-MTAB-8221.

\section{AUTHOR CONTRIBUTIONS}

MO made substantial conceptions to the design of the work, acquisition and interpretation of data.

RJ made substantial contributions to the design of the work, acquisition and interpretation of data.

EG made substantial contributions to the acquisition and interpretation of data.

JL made substantial contributions to the acquisition and interpretation of data.

QF made substantial contributions to the acquisition and interpretation of data.

RS made substantial contributions towards monoclonal antibody generation

AP made substantial contributions to the interpretation of data and drafting of manuscript.

MB made substantial contributions to creation of devices and software.

RZ made substantial contributions regarding the relationship of CELA1 to injured AT2 cells

BV made substantial contributions to the conception and design of the work, interpretation of data, and drafting of the manuscript. 


\section{REFERENCES}

1. M. Ochs, J. R. Nyengaard, A. Jung, L. Knudsen, M. Voigt, T. Wahlers, J. Richter, H. J. Gundersen, The number of alveoli in the human lung, American journal of respiratory and critical care medicine 169, 120-4 (2004).

2. K. Beatty, J. Bieth, J. Travis, Kinetics of association of serine proteinases with native and oxidized alpha-1-proteinase inhibitor and alpha-1-antichymotrypsin, The Journal of biological chemistry 255, 3931-4 (1980).

3. S. Liu, S. M. Young, B. M. Varisco, Dynamic expression of chymotrypsin-like elastase 1 over the course of murine lung development, American journal of physiology. Lung cellular and molecular physiology 306, L1104-16 (2014).

4. A. D. Bird, K. H. Tan, P. F. Olsson, M. Zieba, S. J. Flecknoe, D. R. Liddicoat, R. Mollard, S. B. Hooper, T. J. Cole, Identification of glucocorticoid-regulated genes that control cell proliferation during murine respiratory development, J Physiol 585, 187-201 (2007).

5. R. Joshi, A. Heinz, Q. Fan, S. Guo, B. Monia, C. E. H. Schmelzer, A. S. Weiss, M. Batie, H. Parameshwaran, B. M. Varisco, Role for Cela1 in Postnatal Lung Remodeling and AATdeficient Emphysema, American journal of respiratory cell and molecular biology (2018), doi:10.1165/rcmb.2017-03610C.

6. S. M. Young, S. Liu, R. Joshi, M. R. Batie, M. Kofron, J. Guo, J. C. Woods, B. M. Varisco, Localization and stretch-dependence of lung elastase activity in development and compensatory growth, Journal of applied physiology (Bethesda, Md. : 1985) 118, 921-31 (2015).

7. R. Jesudason, S. Sato, H. Parameswaran, A. D. Araujo, A. Majumdar, P. G. Allen, E. Bartolak-Suki, B. Suki, Mechanical forces regulate elastase activity and binding site availability in lung elastin, Biophysical journal 99, 3076-83 (2010).

8. R. Kohansal, P. Martinez-Camblor, A. Agusti, A. S. Buist, D. M. Mannino, J. B. Soriano, The natural history of chronic airflow obstruction revisited: an analysis of the Framingham offspring cohort, American journal of respiratory and critical care medicine 180, 3-10 (2009).

9. S. He, N. E. Sharpless, Senescence in Health and Disease, Cell 169, 1000-1011 (2017).

10. R. Joshi, S. Liu, M. D. Brown, S. M. Young, M. Batie, J. M. Kofron, Y. Xu, T. E. Weaver, K. Apsley, B. M. Varisco, Stretch regulates expression and binding of chymotrypsin-like elastase 1 in the postnatal lung, FASEB journal : official publication of the Federation of American Societies for Experimental Biology 30, 590-600 (2016).

11. J. Whitsett, Y. Xu, Lung Gene Expression iN Single-cell (LungGENS) (2015) (available at https://research.cchmc.org/pbge/lunggens/default.html).

12. P. A. Reyfman, J. M. Walter, N. Joshi, K. R. Anekalla, A. C. McQuattie-Pimentel, S. Chiu, 
R. Fernandez, M. Akbarpour, C.-I. Chen, Z. Ren, R. Verma, H. Abdala-Valencia, K. Nam, M. Chi, S. Han, F. J. Gonzalez-Gonzalez, S. Soberanes, S. Watanabe, K. J. N. Williams, A. S. Flozak, T. T. Nicholson, V. K. Morgan, D. R. Winter, M. Hinchcliff, C. L. Hrusch, R. D. Guzy, C. A. Bonham, A. I. Sperling, R. Bag, R. B. Hamanaka, G. M. Mutlu, A. V. Yeldandi, S. A. Marshall, A. Shilatifard, L. A. N. Amaral, H. Perlman, J. I. Sznajder, A. C. Argento, C. T. Gillespie, J. Dematte, M. Jain, B. D. Singer, K. M. Ridge, A. P. Lam, A. Bharat, S. M. Bhorade, C. J. Gottardi, G. R. S. Budinger, A. V. Misharin, Single-Cell Transcriptomic Analysis of Human Lung Provides Insights into the Pathobiology of Pulmonary Fibrosis, https://doi.org/10.1164/rccm.201712-2410OC (2018), doi:10.1164/rccm.201712-2410OC.

13. K. A. Riemondy, N. L. Jansing, P. Jiang, E. F. Redente, A. E. Gillen, R. Fu, A. J. Miller, J. R. Spence, A. N. Gerber, J. R. Hesselberth, R. L. Zemans, Single cell RNA sequencing identifies TGF $\beta$ as a key regenerative cue following LPS-induced lung injury, JCI Insight 5 (2019), doi:10.1172/jci.insight.123637.

14. M. Strunz, L. M. Simon, M. Ansari, J. J. Kathiriya, I. Angelidis, C. H. Mayr, G. Tsidiridis, M. Lange, L. F. Mattner, M. Yee, P. Ogar, A. Sengupta, I. Kukhtevich, R. Schneider, Z. Zhao, C. Voss, T. Stoeger, J. H. L. Neumann, A. Hilgendorff, J. Behr, M. O’Reilly, M. Lehmann, G. Burgstaller, M. Königshoff, H. A. Chapman, F. J. Theis, H. B. Schiller, Alveolar regeneration through a Krt8+ transitional stem cell state that persists in human lung fibrosis, Nature Communications 11, 3559 (2020).

15. J. Choi, J.-E. Park, G. Tsagkogeorga, M. Yanagita, B.-K. Koo, N. Han, J.-H. Lee, Inflammatory Signals Induce AT2 Cell-Derived Damage-Associated Transient Progenitors that Mediate Alveolar Regeneration, Cell Stem Cell (2020), doi:10.1016/j.stem.2020.06.020.

16. A. J. Miller, B. R. Dye, D. Ferrer-Torres, D. R. Hill, A. W. Overeem, L. D. Shea, J. R. Spence, Generation of lung organoids from human pluripotent stem cells in vitro, Nature Protocols 14, 518 (2019).

17. Y. Du, J. A. Kitzmiller, A. Sridharan, A. K. Perl, J. P. Bridges, R. S. Misra, G. S. Pryhuber, T. J. Mariani, S. Bhattacharya, M. Guo, S. S. Potter, P. Dexheimer, B. Aronow, A. H. Jobe, J. A. Whitsett, Y. Xu, Lung Gene Expression Analysis (LGEA): an integrative web portal for comprehensive gene expression data analysis in lung development, Thorax (2017), doi:10.1136/thoraxjnl-2016-209598.

18. G. Bandyopadhyay, H. L. Huyck, R. S. Misra, S. Bhattacharya, Q. Wang, J. Mereness, J. A. Lillis, J. R. Myers, J. Ashton, T. Bushnell, M. Cochran, J. Holden-Wiltse, P. Katzman, G. H. Deutsch, J. A. Whitsett, Y. Xu, T. J. Mariani, G. S. Pryhuber, Dissociation, Cellular Isolation and Initial Molecular Characterization of Neonatal and Pediatric Human Lung Tissues, American journal of physiology. Lung cellular and molecular physiology (2018), doi:10.1152/ajplung.00041.2018.

19. N. Neumark, C. Cosme, K.-A. Rose, N. Kaminski, The Idiopathic Pulmonary Fibrosis Cell Atlas, American Journal of Physiology-Lung Cellular and Molecular Physiology 319, L887L892 (2020). 
20. T. S. Adams, J. C. Schupp, S. Poli, E. A. Ayaub, N. Neumark, F. Ahangari, S. G. Chu, B. A. Raby, G. DeIuliis, M. Januszyk, Q. Duan, H. A. Arnett, A. Siddiqui, G. R. Washko, R. Homer, X. Yan, I. O. Rosas, N. Kaminski, Single-cell RNA-seq reveals ectopic and aberrant lungresident cell populations in idiopathic pulmonary fibrosis, Science Advances 6, eaba1983 (2020).

21. A. C. Habermann, A. J. Gutierrez, L. T. Bui, S. L. Yahn, N. I. Winters, C. L. Calvi, L. Peter, M.-I. Chung, C. J. Taylor, C. Jetter, L. Raju, J. Roberson, G. Ding, L. Wood, J. M. S. Sucre, B. W. Richmond, A. P. Serezani, W. J. McDonnell, S. B. Mallal, M. J. Bacchetta, J. E. Loyd, C. M. Shaver, L. B. Ware, R. Bremner, R. Walia, T. S. Blackwell, N. E. Banovich, J. A. Kropski, Single-cell RNA sequencing reveals profibrotic roles of distinct epithelial and mesenchymal lineages in pulmonary fibrosis, Sci Adv 6, eaba1972 (2020).

22. H. Katsura, V. Sontake, A. Tata, Y. Kobayashi, C. E. Edwards, B. E. Heaton, A. Konkimalla, T. Asakura, Y. Mikami, E. J. Fritch, P. J. Lee, N. S. Heaton, R. C. Boucher, S. H. Randell, R. S. Baric, P. R. Tata, Human Lung Stem Cell-Based Alveolospheres Provide Insights into SARSCoV-2-Mediated Interferon Responses and Pneumocyte Dysfunction, Cell Stem Cell 27, 890904.e8 (2020).

23. J. Huang, A. J. Hume, K. M. Abo, R. B. Werder, C. Villacorta-Martin, K.-D. Alysandratos, M. L. Beermann, C. Simone-Roach, J. Lindstrom-Vautrin, J. Olejnik, E. L. Suder, E. Bullitt, A. Hinds, A. Sharma, M. Bosmann, R. Wang, F. Hawkins, E. J. Burks, M. Saeed, A. A. Wilson, E. Mühlberger, D. N. Kotton, SARS-CoV-2 Infection of Pluripotent Stem Cell-Derived Human Lung Alveolar Type 2 Cells Elicits a Rapid Epithelial-Intrinsic Inflammatory Response, Cell Stem Cell 27, 962-973.e7 (2020).

24. R. L. Kusko, J. F. Brothers Ii, J. Tedrow, K. Pandit, L. Huleihel, C. Perdomo, G. Liu, B. Juan-Guardela, D. Kass, S. Zhang, M. Lenburg, F. Martinez, J. Quackenbush, F. Sciurba, A. Limper, M. Geraci, I. Yang, D. A. Schwartz, J. Beane, A. Spira, N. Kaminski, Integrated Genomics Reveals Convergent Transcriptomic Networks Underlying COPD and IPF, American Journal of Respiratory and Critical Care Medicine (2016), doi:10.1164/rccm.201510-2026OC.

25. J. D. Keene, S. Jacobson, K. Kechris, G. L. Kinney, M. G. Foreman, C. M. Doerschuk, B. J. Make, J. L. Curtis, S. I. Rennard, R. G. Barr, E. R. Bleecker, R. E. Kanner, E. C. Kleerup, N. N. Hansel, P. G. Woodruff, M. K. Han, R. Paine 3rd, F. J. Martinez, R. P. Bowler, W. K. O’Neal, Biomarkers Predictive of Exacerbations in the SPIROMICS and COPDGene Cohorts, American journal of respiratory and critical care medicine 195, 473-481 (2017).

26. P. G. Woodruff, R. G. Barr, E. Bleecker, S. A. Christenson, D. Couper, J. L. Curtis, N. A. Gouskova, N. N. Hansel, E. A. Hoffman, R. E. Kanner, E. Kleerup, S. C. Lazarus, F. J. Martinez, R. Paine, S. Rennard, D. P. Tashkin, M. K. Han, SPIROMICS Research Group, Clinical Significance of Symptoms in Smokers with Preserved Pulmonary Function, N. Engl. J. Med. 374, 1811-1821 (2016).

27. 1000 Genomes Project Consortium, A. Auton, L. D. Brooks, R. M. Durbin, E. P. Garrison, H. M. Kang, J. O. Korbel, J. L. Marchini, S. McCarthy, G. A. McVean, G. R. Abecasis, A global reference for human genetic variation, Nature 526, 68-74 (2015). 
medRxiv preprint doi: https://doi.org/10.1101/2020.04.27.20075531; this version posted January 16, 2021. The copyright holder for this preprint (which was not certified by peer review) is the author/funder, who has granted medRxiv a license to display the preprint in perpetuity. All rights reserved. No reuse allowed without permission.

28. Home - dbGaP - NCBI (available at https://www.ncbi.nlm.nih.gov/gap/).

29. M. J. Landrum, J. M. Lee, G. R. Riley, W. Jang, W. S. Rubinstein, D. M. Church, D. R. Maglott, ClinVar: public archive of relationships among sequence variation and human phenotype, Nucleic Acids Res 42, D980-D985 (2014).

30. I. Adzhubei, D. M. Jordan, S. R. Sunyaev, Predicting functional effect of human missense mutations using PolyPhen-2, Curr Protoc Hum Genet Chapter 7, Unit7.20-Unit7.20 (2013).

31. N.-L. Sim, P. Kumar, J. Hu, S. Henikoff, G. Schneider, P. C. Ng, SIFT web server: predicting effects of amino acid substitutions on proteins, Nucleic Acids Res 40, W452-W457 (2012).

32. S. Janciauskiene, T. Welte, Well-Known and Less Well-Known Functions of Alpha-1 Antitrypsin. Its Role in Chronic Obstructive Pulmonary Disease and Other Disease Developments, Annals of the American Thoracic Society 13 Suppl 4, S280-8 (2016).

33. M. G. Foreman, C. Wilson, D. L. DeMeo, C. P. Hersh, T. H. Beaty, M. H. Cho, J. Ziniti, D. Curran-Everett, G. Criner, J. E. Hokanson, M. Brantly, F. N. Rouhani, R. A. Sandhaus, J. D. Crapo, E. K. Silverman, Alpha-1 Antitrypsin PI MZ Genotype Is Associated with COPD in Two Racial Groups, Annals of the American Thoracic Society (2017), doi:10.1513/AnnalsATS.201611-8380C.

34. R. Busch, B. D. Hobbs, J. Zhou, P. J. Castaldi, M. J. McGeachie, M. E. Hardin, I. Hawrylkiewicz, P. Sliwinski, J. J. Yim, W. J. Kim, D. K. Kim, A. Agusti, B. J. Make, J. D. Crapo, P. M. Calverley, C. F. Donner, D. A. Lomas, E. F. Wouters, J. Vestbo, R. Tal-Singer, P. Bakke, A. Gulsvik, A. A. Litonjua, D. Sparrow, P. D. Pare, R. D. Levy, S. I. Rennard, T. H. Beaty, J. Hokanson, E. K. Silverman, M. H. Cho, Genetic Association and Risk Scores in a COPD Meta-Analysis of 16,707 Subjects, American journal of respiratory cell and molecular biology (2017), doi:10.1165/rcmb.2016-03310C.

35. L. J. Donato, S. M. Jenkins, C. Smith, J. A. Katzmann, M. R. Snyder, Reference and Interpretive Ranges for a 1-Antitrypsin Quantitation by Phenotype in Adult and Pediatric Populations, Am J Clin Pathol 138, 398-405 (2012).

36. N. Guyot, J. Wartelle, L. Malleret, A. A. Todorov, G. Devouassoux, Y. Pacheco, D. E. Jenne, A. Belaaouaj, Unopposed cathepsin G, neutrophil elastase, and proteinase 3 cause severe lung damage and emphysema, The American journal of pathology 184, 2197-210 (2014).

37. S. D. Shapiro, N. M. Goldstein, A. M. Houghton, D. K. Kobayashi, D. Kelley, A. Belaaouaj, Neutrophil elastase contributes to cigarette smoke-induced emphysema in mice, The American journal of pathology 163, 2329-35 (2003).

38. P. Golovatch, B. A. Mercer, V. Lemaitre, A. Wallace, R. F. Foronjy, J. D'Armiento, Role for cathepsin $\mathrm{K}$ in emphysema in smoke-exposed guinea pigs, Exp Lung Res 35, 631-45 (2009).

39. R. D. Hautamaki, D. K. Kobayashi, R. M. Senior, S. D. Shapiro, Requirement for 
medRxiv preprint doi: https://doi.org/10.1101/2020.04.27.20075531; this version posted January 16, 2021. The copyright holder for this preprint (which was not certified by peer review) is the author/funder, who has granted medRxiv a license to display the preprint in perpetuity.

All rights reserved. No reuse allowed without permission.

macrophage elastase for cigarette smoke-induced emphysema in mice, Science (New York, N.Y.) 277, 2002-4 (1997).

40. W. Saitoh, T. Sakamoto, A. E. Hegab, A. Nomura, Y. Ishii, Y. Morishima, S. Kai, T. Iizuka, T. Kiwamoto, Y. Matsuno, H. H. Massoud, H. M. Massoud, K. M. Hassanein, K. Sekizawa, MMP14 gene polymorphisms in chronic obstructive pulmonary disease, International journal of molecular medicine 17, 621-6 (2006).

41. I. Haq, G. E. Lowrey, N. Kalsheker, S. R. Johnson, Matrix metalloproteinase-12 (MMP-12) SNP affects MMP activity, lung macrophage infiltration and protects against emphysema in COPD, Thorax 66, 970-6 (2011).

42. M. V. Oliveira, S. C. Abreu, G. A. Padilha, N. N. Rocha, L. A. Maia, C. M. Takiya, D. G. Xisto, B. Suki, P. L. Silva, P. R. Rocco, Characterization of a Mouse Model of Emphysema Induced by Multiple Instillations of Low-Dose Elastase, Front Physiol. 7 (2016).

43. M. S. Dunnill, Quantative Methods in the Study of Pulmonary Pathology, Thorax 17, 320328 (1962).

44. B. Suki, E. Bartolak-Suki, P. R. M. Rocco, Elastase-Induced Lung Emphysema Models in Mice, Methods Mol Biol. 1639 (2017), doi:10.1007/978-1-4939-7163-3_7.

45. M. Nagendran, D. P. Riordan, P. B. Harbury, T. J. Desai, J. Rajagopal, Ed. Automated celltype classification in intact tissues by single-cell molecular profiling, eLife 7, e30510 (2018).

46. Ensembl genome browser 98 (available at https://useast.ensembl.org/index.html).

47. R Core Team, R: A Language and Environment for Statistical Computing (R Foundation for Statistical Computing, Vienna, Austria, 2019; https://www.R-project.org/).

48. ggpubr: Publication Ready Plots - Articles - STHDA (available at http://www.sthda.com/english/articles/24-ggpubr-publication-ready-plots/).

49. B. Auguie, gridExtra: Miscellaneous Functions for "Grid” Graphics (2017; https://CRAN.R-project.org/package=gridExtra).

50. C. O. Wilke, cowplot: Streamlined Plot Theme and Plot Annotations for "ggplot2" (2019; https://CRAN.R-project.org/package=cowplot).

51. G. Yu, ggplotify: Convert Plot to "grob” or "ggplot” Object (2019; https://CRAN.Rproject.org/package $=$ ggplotify $)$.

52. T. Wei, V. Simko, R package "corrplot": Visualization of a Correlation Matrix (2017; https://github.com/taiyun/corrplot).

53. A. Kassambara, rstatix: Pipe-Friendly Framework for Basic Statistical Tests (2020; https://CRAN.R-project.org/package=rstatix). 
medRxiv preprint doi: https://doi.org/10.1101/2020.04.27.20075531; this version posted January 16, 2021. The copyright holder for this preprint (which was not certified by peer review) is the author/funder, who has granted medRxiv a license to display the preprint in perpetuity.

All rights reserved. No reuse allowed without permission.

54. Lung alveolar type 2 cell (AT2) response to SARS-CoV-2 (available at https://crem.shinyapps.io/iAEC2infection/).

55. A molecular cell atlas of the human lung from single-cell RNA sequencing | Nature (available at https://www.nature.com/articles/s41586-020-2922-4).

56. Comprehensive Integration of Single-Cell Data: Cell (available at https://www.cell.com/cell/fulltext/S0092-8674(19)30559-8).

57. S. J. Dorry, B. O. Ansbro, D. M. Ornitz, G. M. Mutlu, R. D. Guzy, FGFR2 is Required for AEC2 Homeostasis and Survival Following Bleomycin-Induced Lung Injury, Am J Respir Cell Mol Biol (2019), doi:10.1165/rcmb.2019-0079OC. 